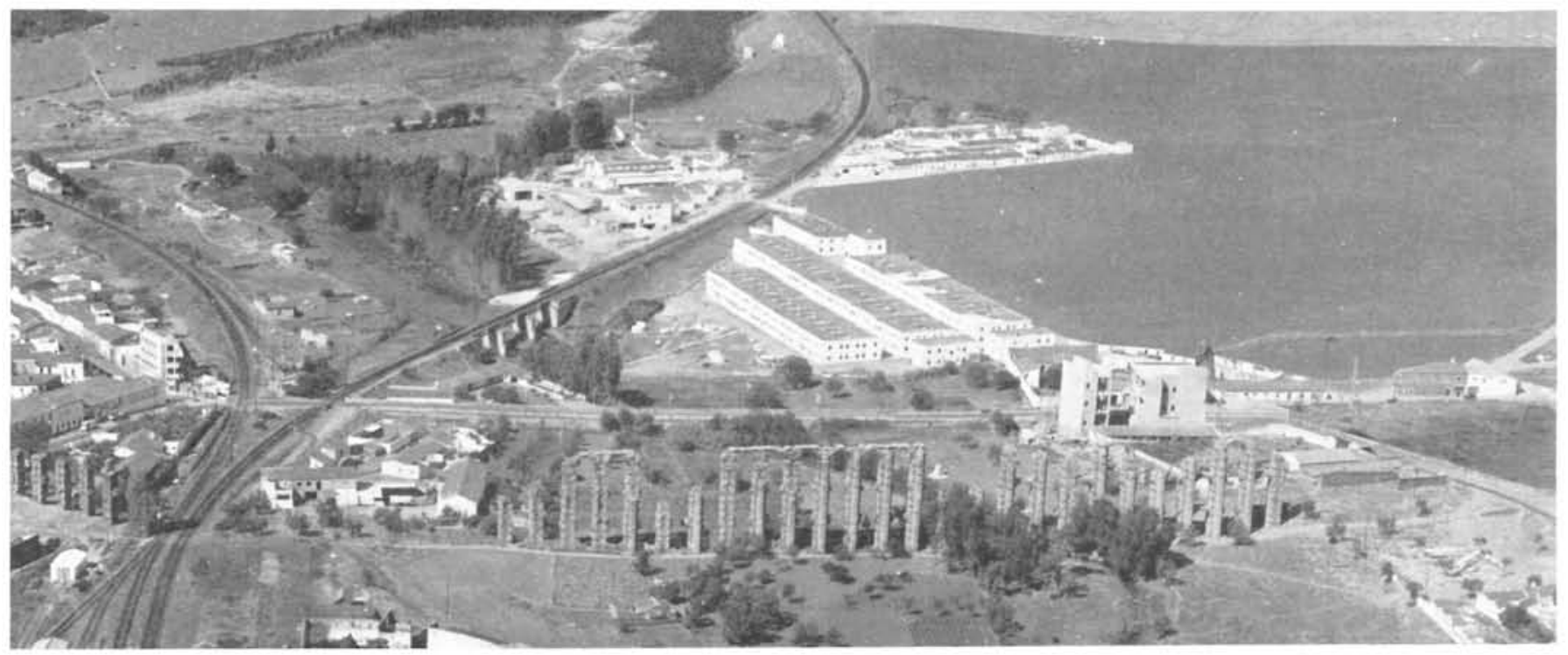

$535 \cdot 5$

\title{
acueductos de Mérida
}

Dos vistas aéreas del acueducto de Los Milagros.

C. FERNANDEZ CASADO, Dr. Ingeniero de Caminos

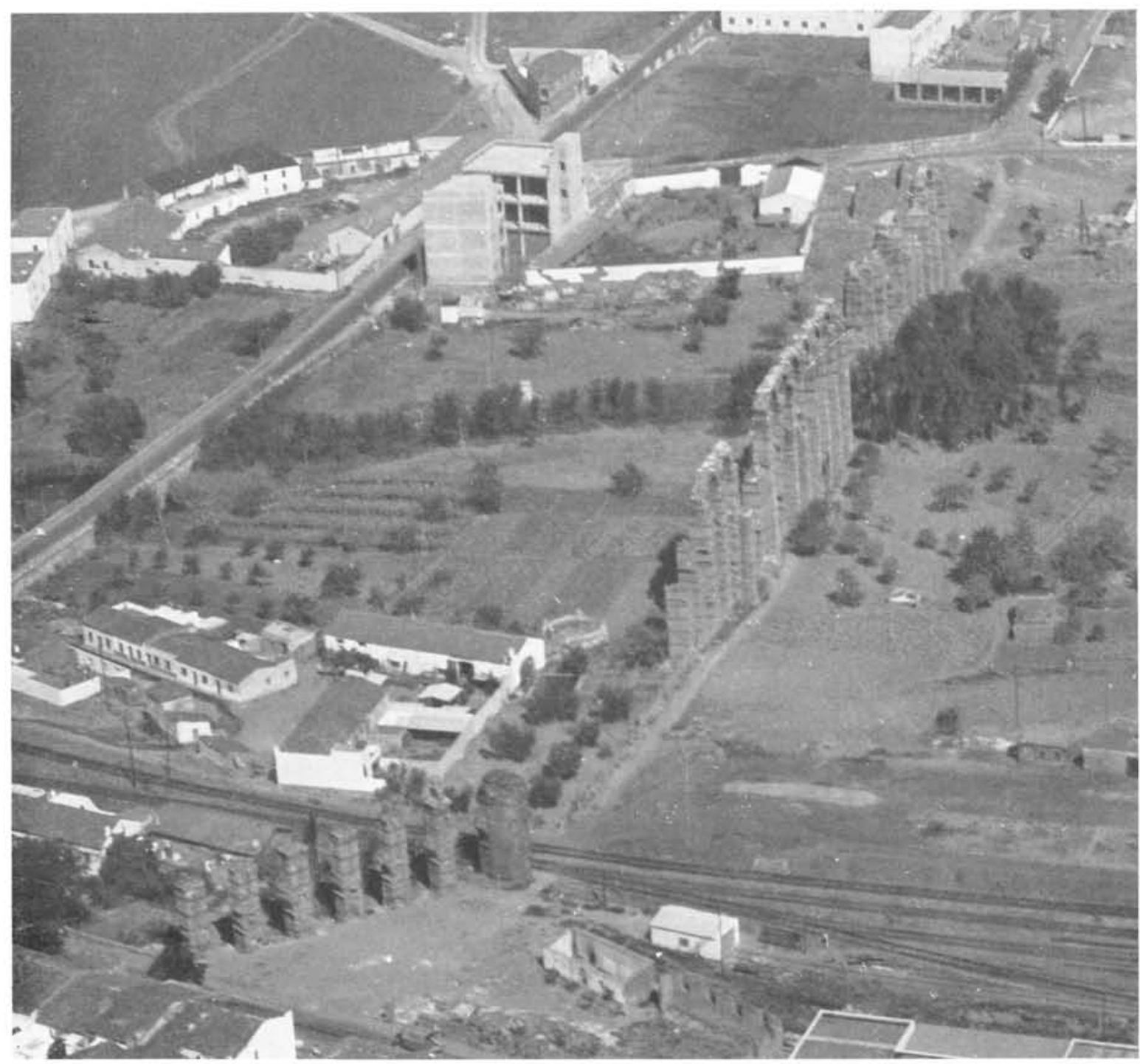




\section{I conducciones}

El abastecimiento de agua a Mérida (Emérita Augusta) se realiza al final de la romanidad por tres conducciones completamente independientes, de épocas distintas y con organización muy diferente, por las condiciones técnicas que caracterizan a cada una. De ninguna de ellas se tiene conocimiento documental, asideros epigráficos, o referencias literarias de su época, y sería muy interesante poder establecer la antigüedad de las conducciones, ya que esto arrojaría bastante luz para la datación de las obras monumentales correspondientes.

Se designan estas conducciones por Cornalvo, Proserpina y Rabo-de-Buey o de las Tomas, no correspondiendo estos nombres a nada romano. La designación de Cornalvo, que aparece en la Edad Media, se refiere al aspecto del fondo seco del embalse que tiene forma de creciente y relumbre blanquecino, debido al sedimento salino. El nombre de Proserpina se tomó de la invocación a esta deidad en una lápida encontrada cerca de la presa correspondiente, pero sin relación alguna con ella. Las dos designaciones de la tercera se refieren a la disposición ramificada que tiene la conducción en su origen, por aportación sucesiva de las tomas de distintos manantiales.

Dos de las conducciones comienzan reteniendo agua en un embalse mediante su correspondiente presa de fábrica, habiéndose mejorado en ambas la aportación por trasvase de agua de los valles inmediatos. En una de ellas, Cornalvo, la canal es muy larga pues resultan más de $20 \mathrm{~km}$, siendo casi toda enterrada, mientras que en Proserpina sólo tenemos $6 \mathrm{~km}$ y va por la superficie.

En la tercera se toma el agua de manantiales próximos a la ciudad y, por tanto, la longitud de conducción es bastante reducida, pero le correspondía un acueducto muy importante para cruzar el valle de Albarregas, a cuyas ruinas, de sólo dos tramos, se les-denomina de San Lázaro.

Parece ser que la conducción de Proserpina era para fines industriales, lo cual justifica su realización en canal superficial sin cubrir; en cambio, tanto Cornalvo como Rabode-Buey van enterradas en galería con obras elevadas únicamente al cortar depresiones importantes, dos en aquélla y una en ésta. Estaban balizadas por registros a distancias iguales, que son muy exactas en la última.

La canal de Cornalvo, que, como ya hemos dicho, va casi toda en galería subterránea, comienza captando aguas subálveas en su zona alta, donde está el nacimiento del Albarregas, con encharcamientos, primero, y cauce relleno de sedimentos, después. Se conservan algunos registros que actualmente sirven de pozos para captar el agua de la galería. Al quedar francamente en ladera después de pasar el pueblo actual de Trujillanos va más superficial y queda aparente en algunas vaguadas, elevándose sobre arcos en las dos últimas. En la penúltima, que es la de Cañoquebrado, denominada así precisamente por los restos que aparecen de la conducción, debió haber una obra de varios arcos, puesto que la rasante se despega francamente del terreno, aunque sólo quedan los muros triangulares de ambos extremos, extendiéndose el de aguas arriba discontinuamente en unos $60 \mathrm{~m}$ hasta remontar los $4 \mathrm{~m}$ en coronación. Del otro lado queda la caja a la vista en curva con longitud inferior a $10 \mathrm{~m}$, volviendo en seguida a enterrarse.

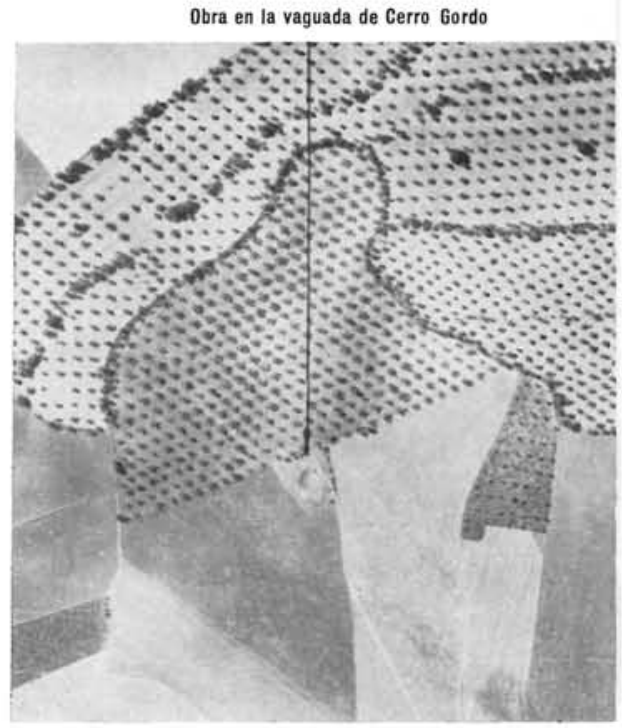

Cloaca del an

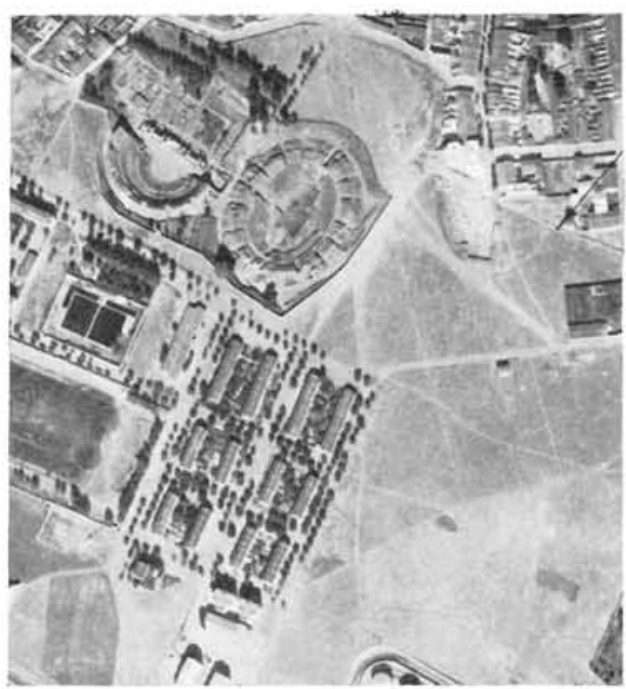

Ermita di

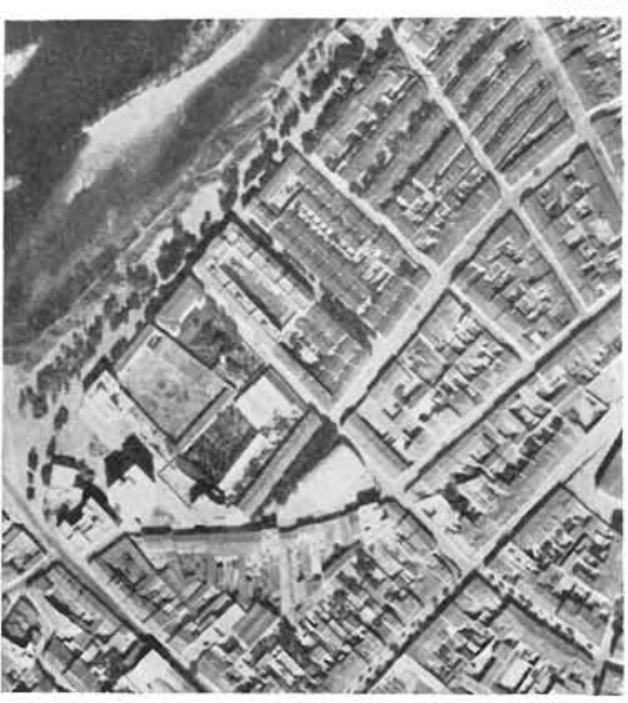

Depósito 


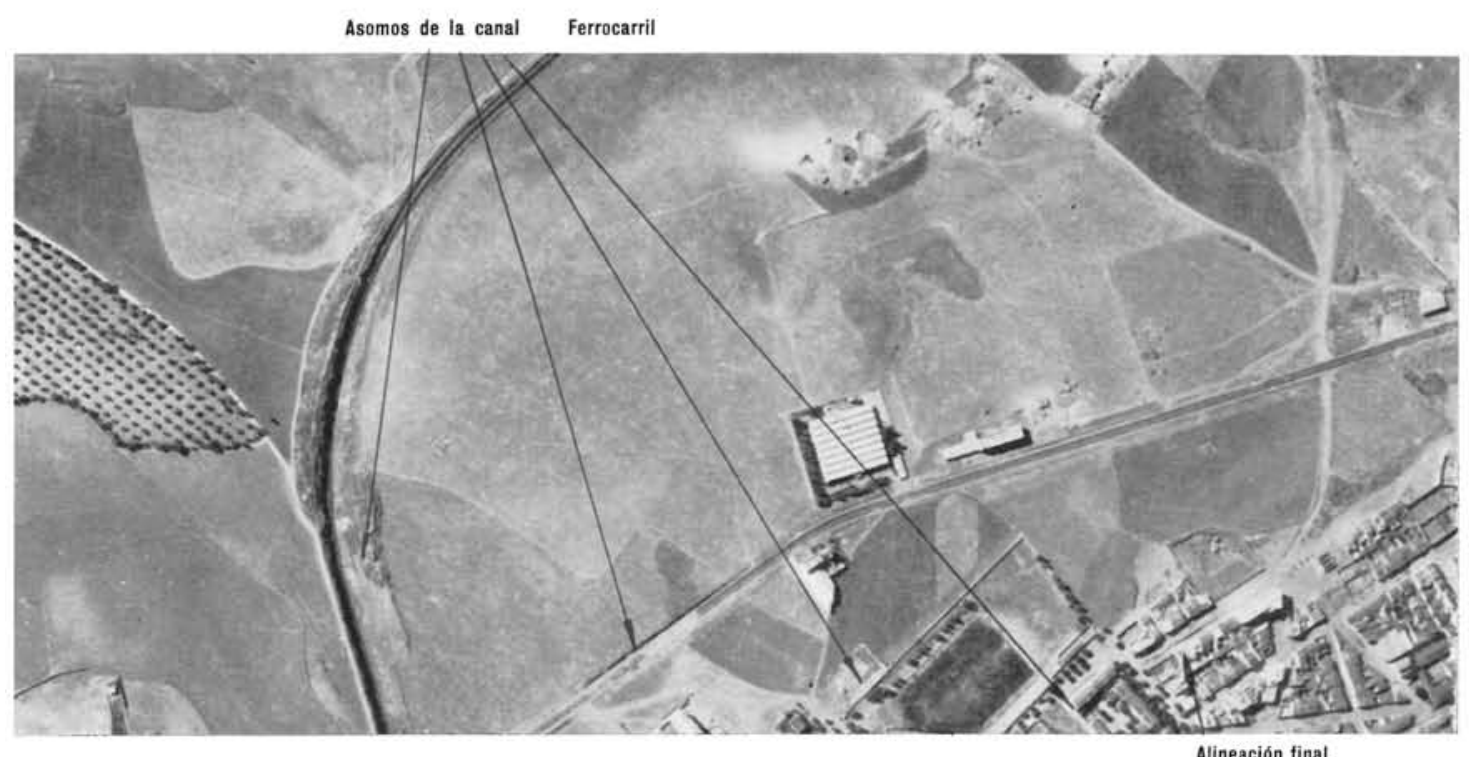

zona final de la conducción de Cornalvo

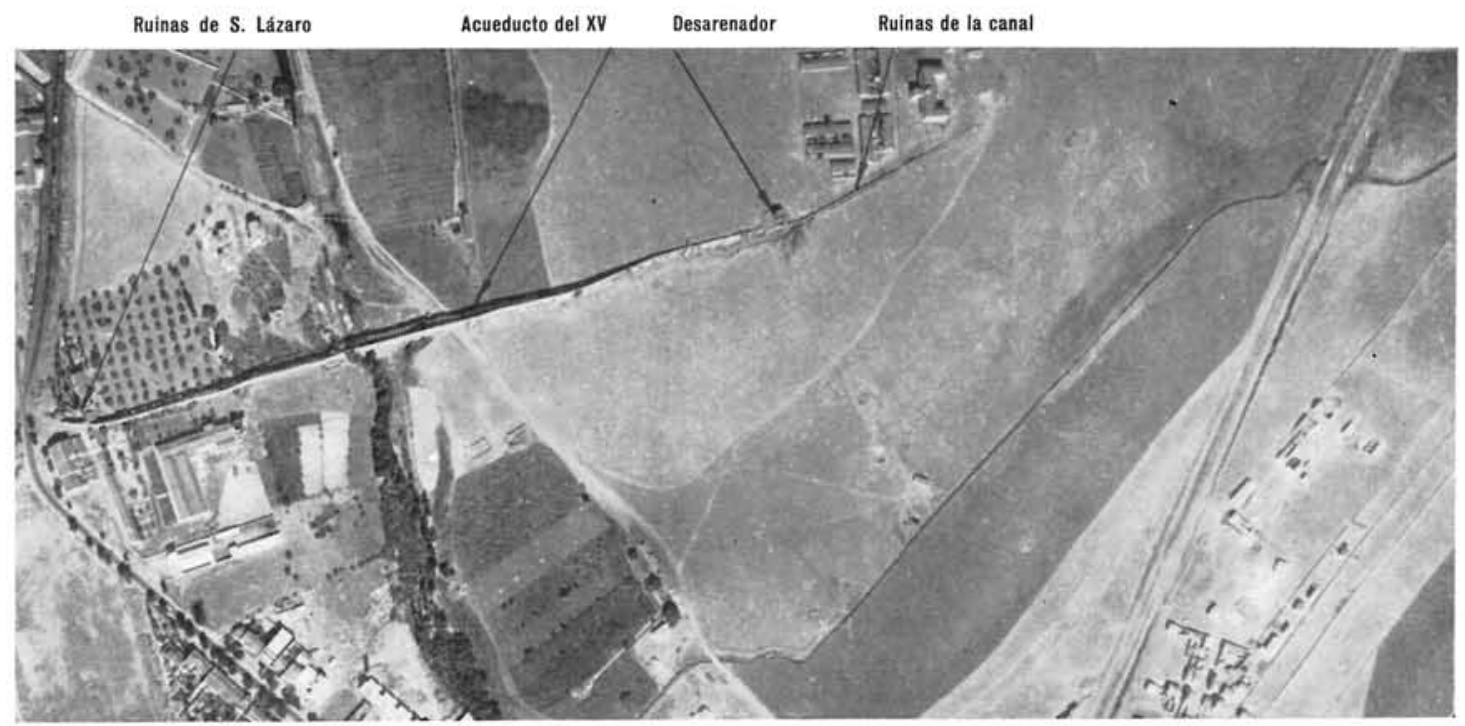

zona final de la conducción de Rabo-de-Buey

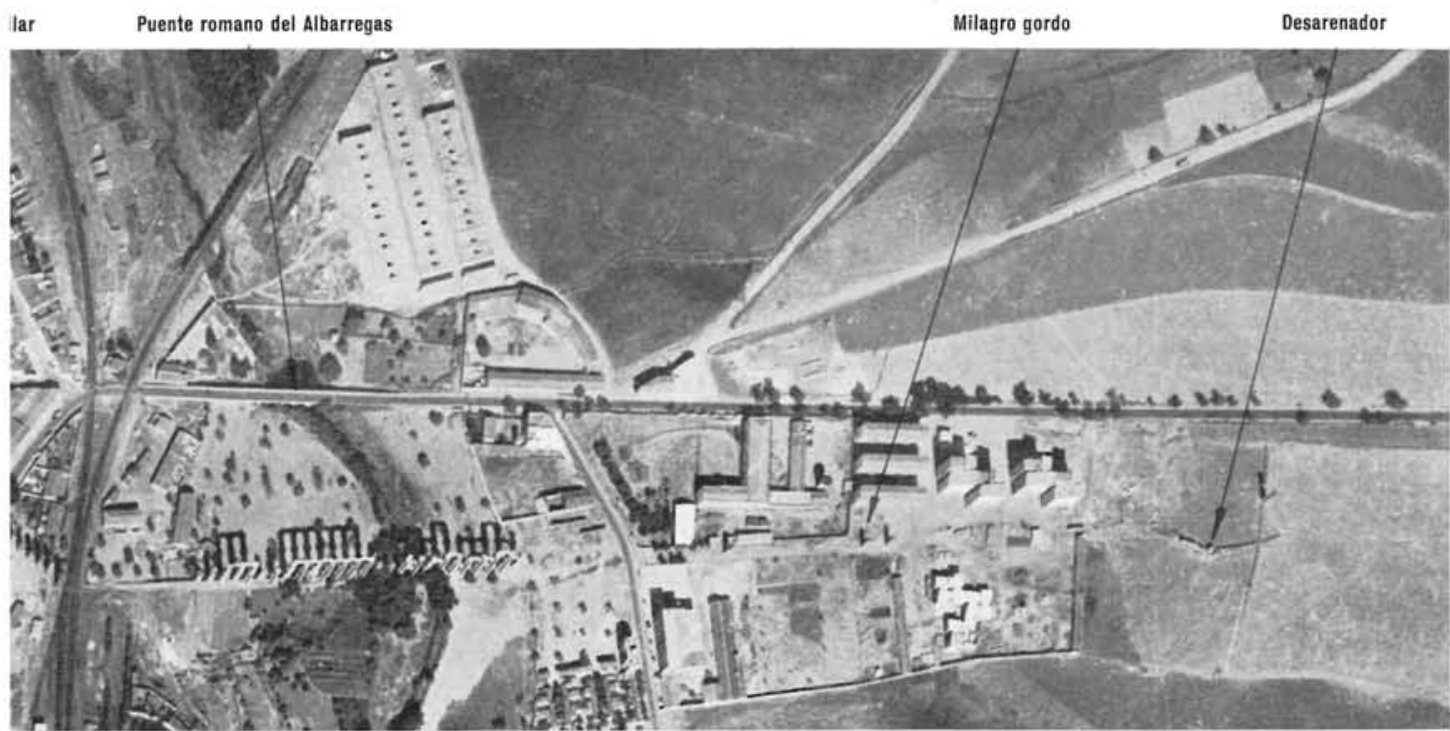



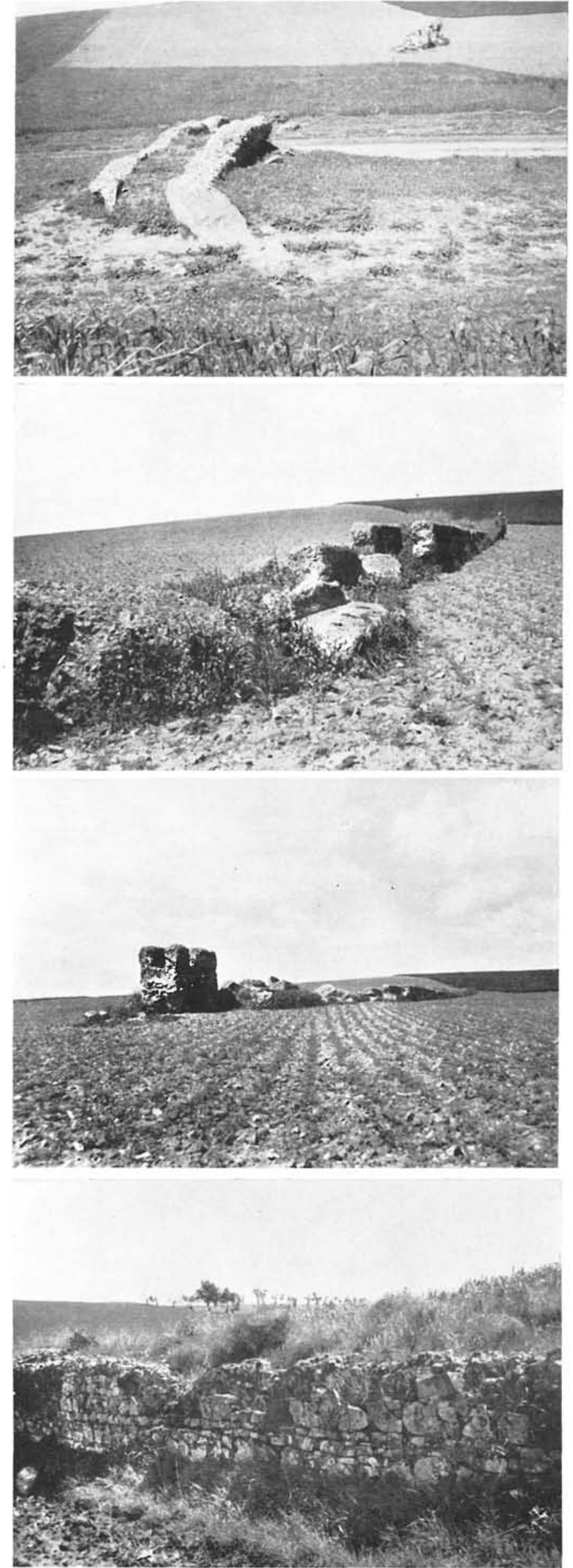

\section{obras visibles}

en la conducción de Cornalvo

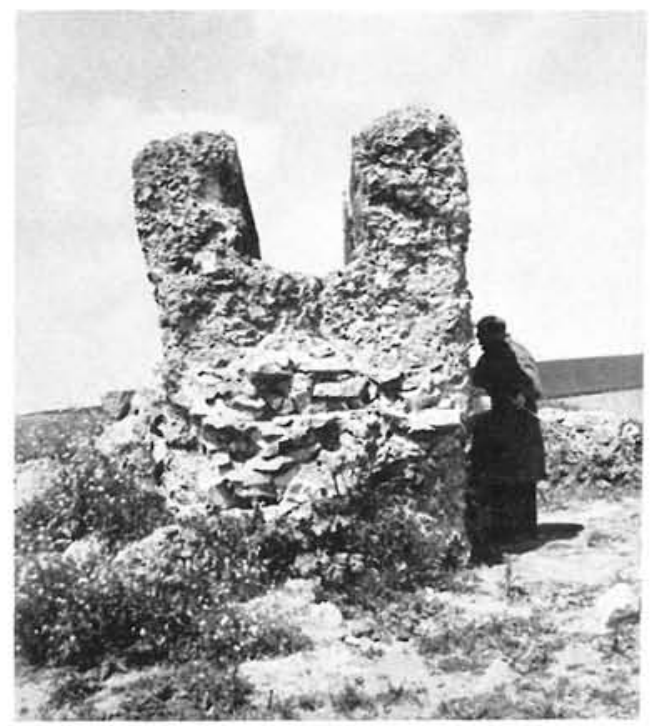

Obra en la vaguada de Caño Quebrado.

Por esta vaguada sube la carretera del pueblo de Valverde, desde la general de Extremadura, quedando estos restos muy próximos del $\mathrm{km} 2$ de la misma. La fábrica es un hormigón de gruesos cantos y debía estar revestida de mampostería que se arrancaría para nuevo empleo.

La obra de la vaguada siguiente, que se denomina de Cerro Gordo, es más simple, pues

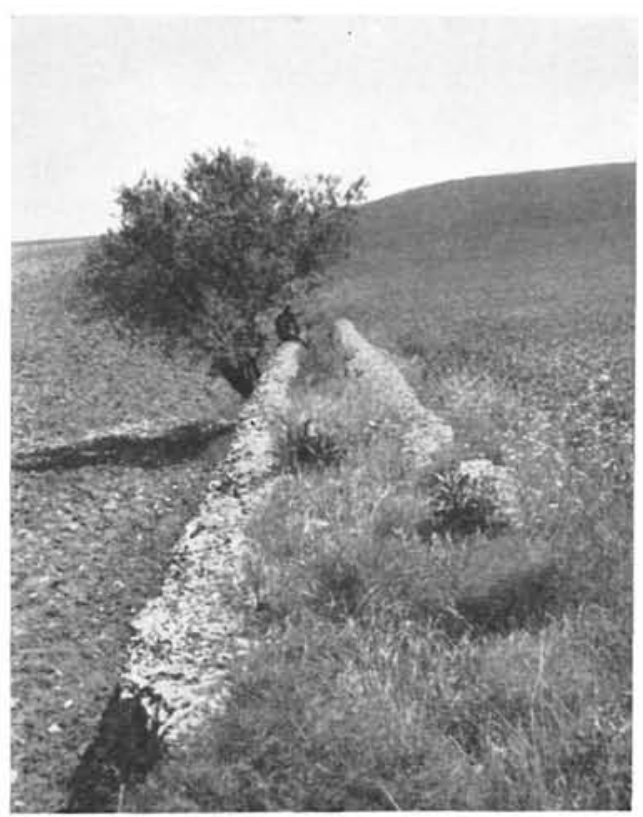

Asomo con muro y alcantarilla en la vaguada de Cerro Gordo. 
conducción de Cornalvo
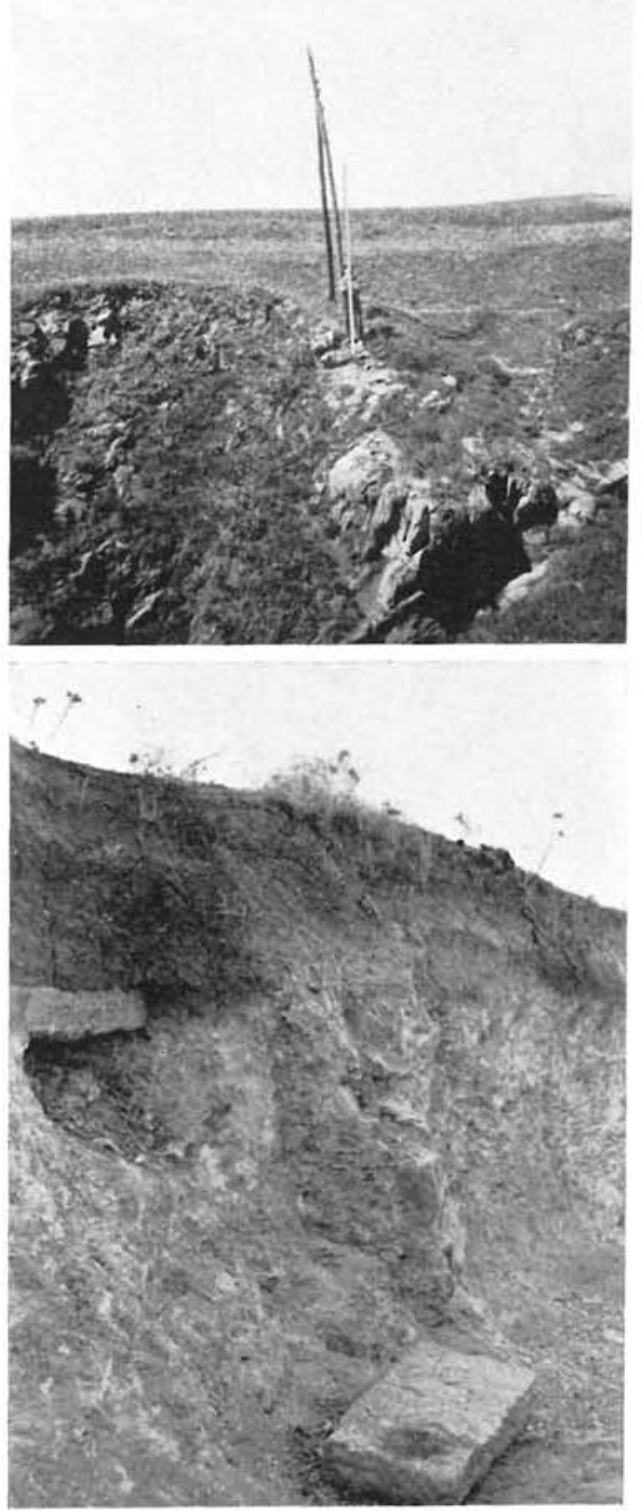

Alineación final.

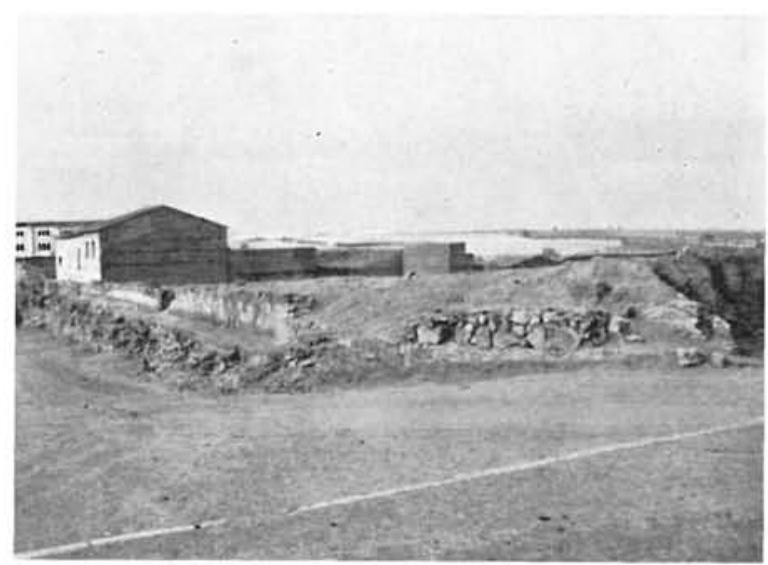

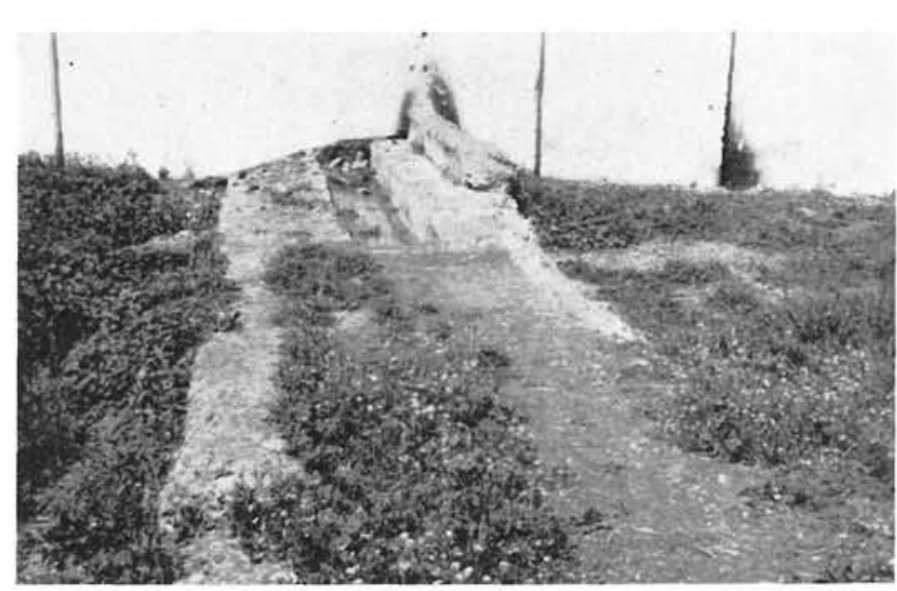

Corte en la trinchera del ferrocarril.

La canal atravesando la tapia del campo de fútbol.

Corte en el talud de la carretera.

la canal se eleva sobre muros en unos $30 \mathrm{~m}$ de recorrido, teniendo en el centro una alcantarilla de $0,86 \mathrm{~m}$ de luz con aliviadero de descarga. El muro se conserva casi intacto con su revestimiento de mampostería.

Los restantes asomos de la canal hasta llegar a la antigua muralla son accidentales, y así tenemos un corte en el talud de la carretera actual (ronda externa), donde iba muy cerca de la superficie y se conservan las losas de tapa que la cubrían. A continuación tenemos el corte correspondiente a la trinchera del ferrocarril, donde aparece la solera y parte de los cajeros, señalando una alineación que la volvemos a encontrar atravesando la tapia del campo de fútbol y continuando dentro, aunque la explanación del mismo ha dejado arrasada la obra hasta nivel de solera. Después asoma su coronación junto al cuartel de la Guardia Civil, pasando por debajo del edificio, para volver a aparecer sobre el nuevo recinto de esa zona, llegando hasta una explanada que sirvió de era, y que creemos debe rellenar la piscina limaria de la conducción. Esta explanación queda muy cerca de la plaza de toros y está en un lugar dominante de la ciudad antigua muy a propósito para iniciar la distribución de las aguas.

Ruinas del canal sobre la muralla.

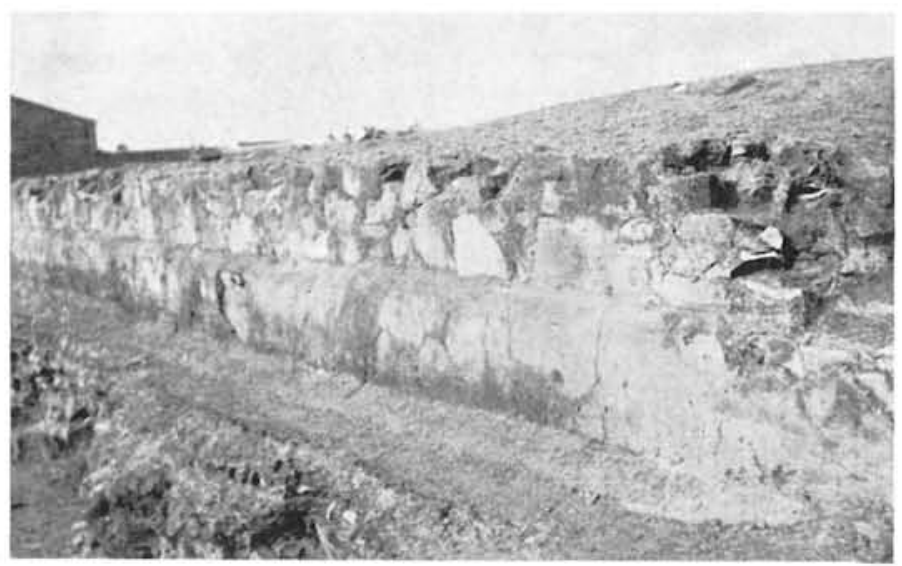



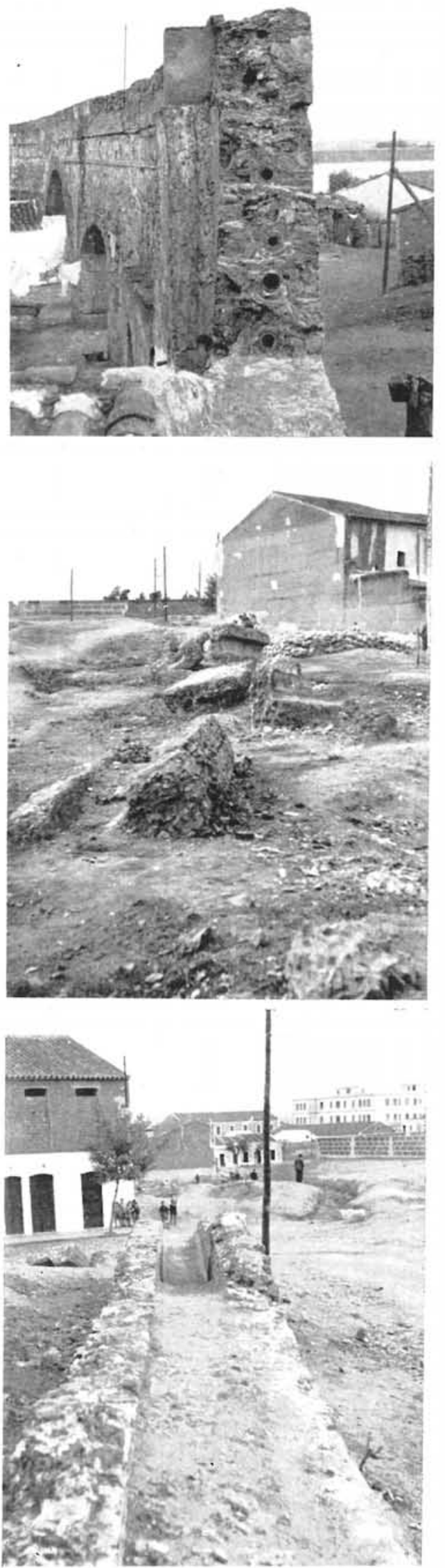

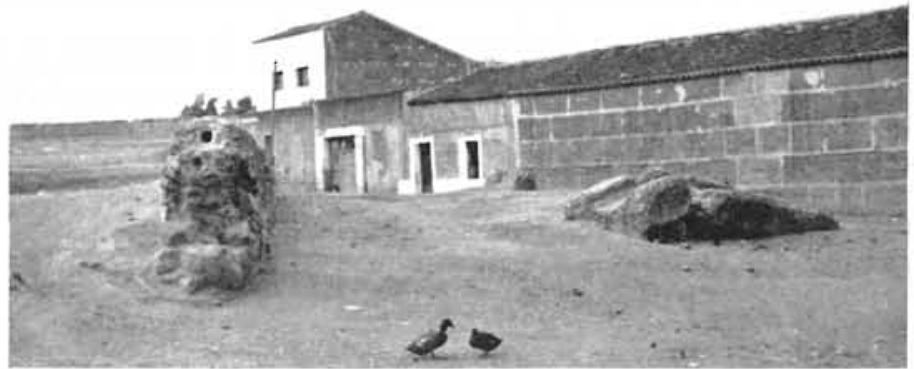

Restos de la canal romana y de la cañería del XV en la explanada de Manuel Guerrero.

Final del acueduc to del siglo XV que agua encañada.
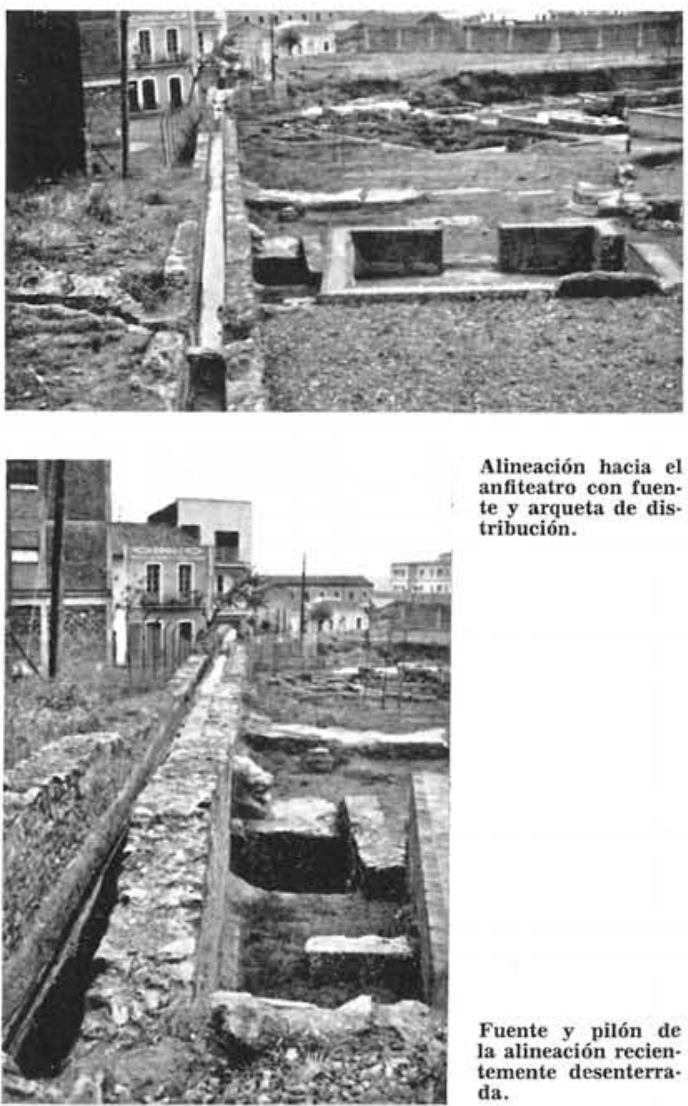

Alineación hacia el anfiteatro con fuen. ribución.
Restos de la canal romana.

La canal hacia el desenterrarla.

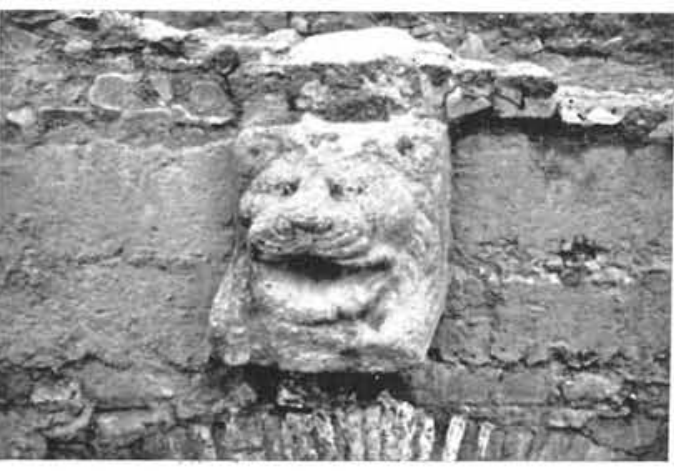

Cabeza de león de la fuente. 


\section{conducción de Proserpina}

Detalle de la fábrica del muro con

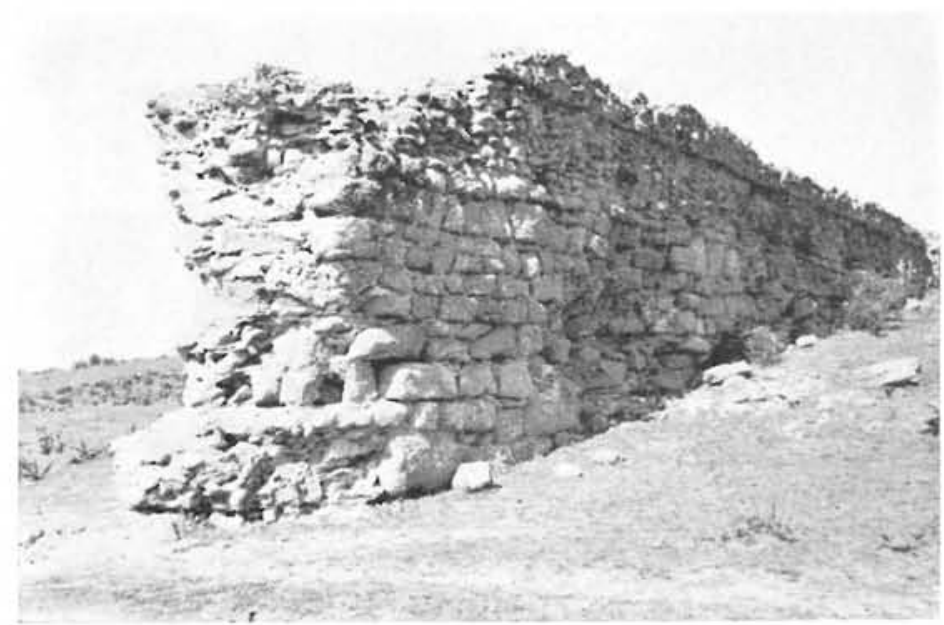

Esta conducción no tiene otra obra aparente importante, salvo la presa originaria. Su disposición en galería enterrada parece indicar que servía a fines domésticos, lo cual nos invita a creer que es la primera conducción, y además pudiera haber tenido una época inicial sin presa, por captación directa de las aguas del río en su zona alta.

La conducción de Rabo-de-Buey también parece haber conducido agua doméstica, por su naturaleza de galería enterrada, aunque también podría haber servido al circo (fuentes en la espina), como luego indicaremos, y con seguridad al anfiteatro, pues la alineación final se dirige hacia dicho monumento.

Esta conducción, de unos $2 \mathrm{~km}$ de longitud, después de reunir las diversas tomas tenía un pequeño acueducto de un arco, para en seguida, a la salida de un desarenador, quedarse elevada sobre un monumental acueducto, del cual permanecen actualmente en pie las insignificantes ruinas de tres pilares y dos arcos. Este acueducto, que debía estar ya arruinado en la Edad Media, suministró sus piedras para la defectuosa fábrica de un ondulante acueducto construido en el siglo XV que, con su torpeza, realza la perfección y belleza de las ruinas de los dos acueductos romanos de Mérida.

El acueducto del siglo XV, con una sucesión de arcos desiguales y diversas fábricas: mampostería sillares romanos e hiladas de ladrillo en pilares y tímpanos, llevaba el agua encañada a diversas alturas, no sabemos si desde el principio, pero en la actualidad observamos en el corte final hasta seis tuberías cerámicas de diámetros diversos con concreciones calizas de bastante espesor. Estas tuberías vuelven a encontrarse en las ruinas que aparecen cortadas en la explanada de Manuel Guerrero.

La conducción primitiva se abandonó completamente desde el desarenador, apareciendo actualmente su canal derribada en largos tramos rectos que correspondían a la primera parte de la alineación sobre muros. Después de salir del acueducto se ha perdido en toda la zona que corresponde a las edificaciones actuales del cuartel de Artillería, reapareciendo en la explanada de Manuel Guerrero con pocos vestigios in situ, y largos trozos volcados por el suelo, terminando en una larga alineación recta que se dirige hacia el anfiteatro y que se encontraba parcialmente enterrada hasta hace pocos años. Al realizar excavaciones en la denominada "Casa del Anfiteatro" se desenterró todo este trozo de la conducción que iba entre muros bastante profundos, apareciendo una cabeza de león - adosada al muro del lado de la ciudad-que servía de fuente pública con el pilón correspondiente, y a continuación una arqueta rectangular para distribución de parte del agua hacia la población. También suministraba a la citada Casa del Anfiteatro, y el resto se dirigía a este anfiteatro, que tenía una cloaca de desagüe muy importante, conservada en la actualidad. El anfiteatro debía servir parcialmente de naumaquia llenando el foso que existe en todos los monumentos análogos y que se utilizaba para albergar fieras y guardar enseres, quedando cubiertos a nivel de la arena con tablas cuando se utilizaban propiamente. En Mérida tenemos el fondo y paredes revestidas de opus signinum con las aristas entrantes defendidas por cordones en cuarto de círculo del mismo revestimiento, lo cual denota que estaba asegurada su estanquidad. Esta misma conducción debía servir, como ya hemos indicado, al circo, ya que desde el final del acueducto quedaban muy próximas las cárceres y además existen en las dos extremidades de la espina estanques circulares revestidos de opus signinum que servían a fuentes y quizas surtidores. 


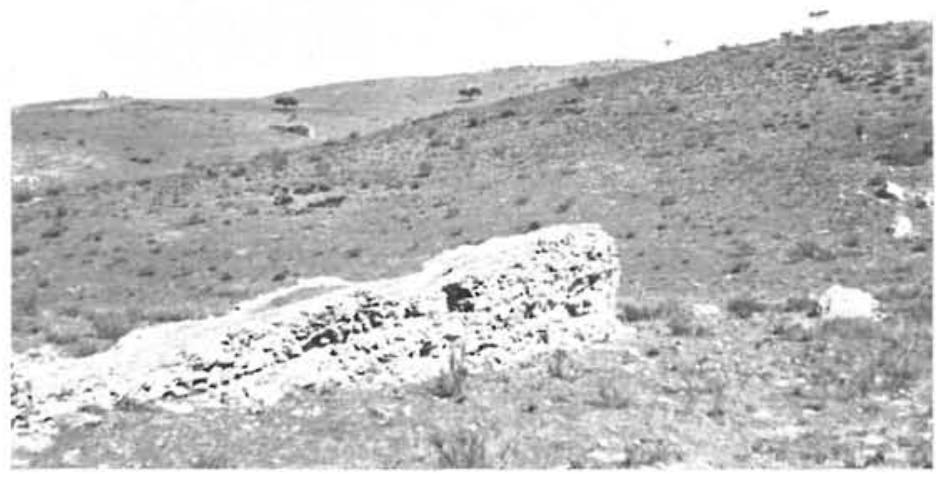

Final de la obra en la vaguada III: Al fondo se ve la cabeza de la obra de la vaguada II.

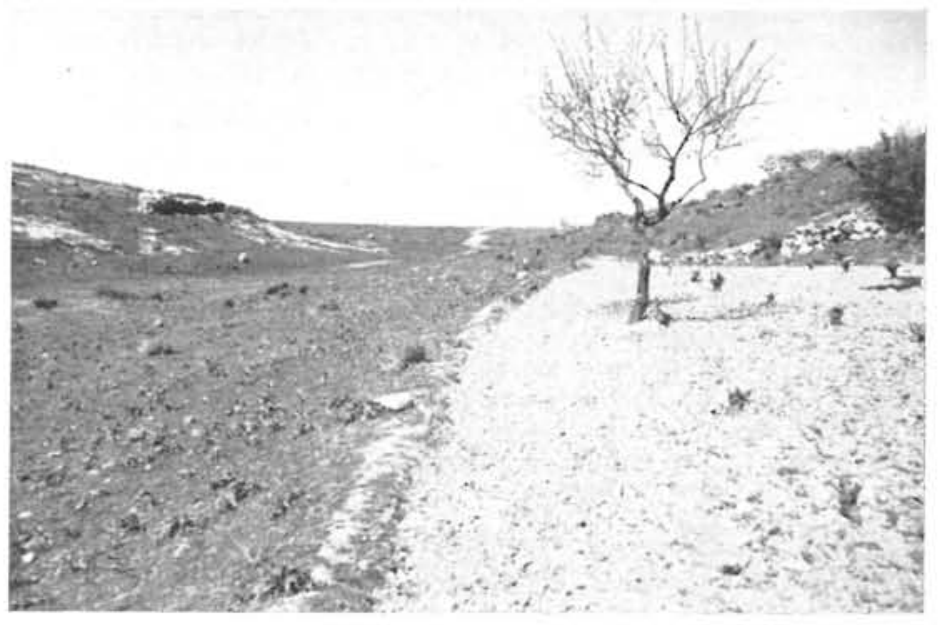

Cambio de ladera en el puerto de Carija.

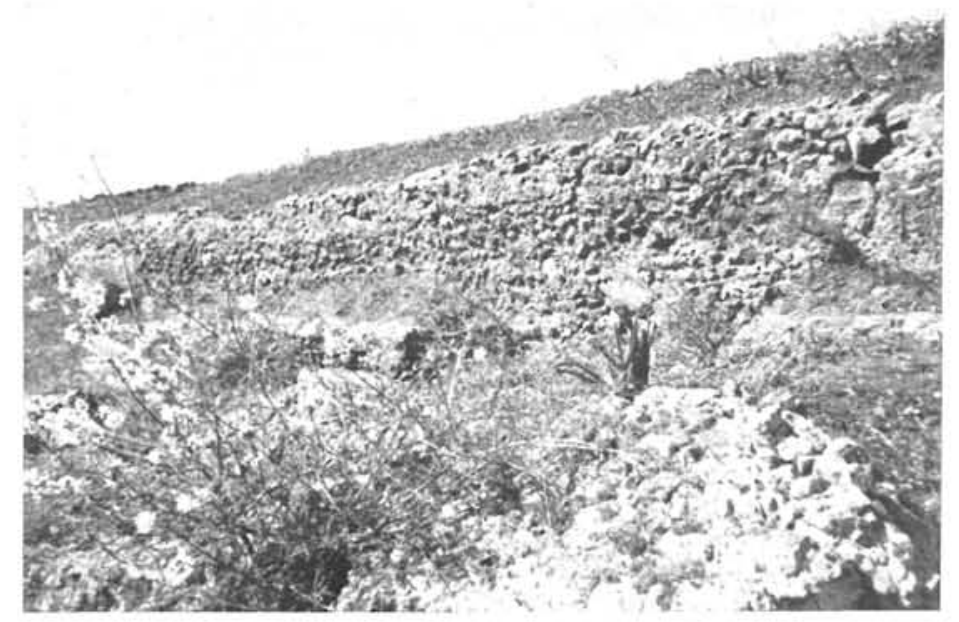

La tercera conducción, la de Proserpina, que creemos lo es así en orden cronológico, tenía como final el gran acueducto, denominado de Los Milagros por la asombrosa magnitud y verticalidad de sus pilares, y llegaba a él desde el embalse de cabecera después de recorrer unos $6 \mathrm{~km}$ en canal superficial cortando varios barrancos en obra elevada seguramente sobre arcos.

Las más importantes de estas obras debían estar en ias tres primeras vaguadas que se atraviesan después de abandonar la correspondiente a la cerrada por la presa. Estas vaguadas tienen poca pendiente y hubieran dado lugar a un gran contorneo y, por ello, se cortaron con tres obras de las que no quedan nada más que los arranques en muro de fábrica; pero como en el corte recto la rasante del canal llega a tomar cotas de $15 \mathrm{~m}$, es lógico que la obra se haya desarrollado sobre arcadas (arcuationibus) en la zona central. Además, no quedan restos de un cimiento corrido que hubiera correspondido a muro continuo y, en cambio, hay señales de remoción del terreno en puntos intermedios como si hubieran rebuscado los sillares de apoyo de los pilares. Las zonas triangulares que hoy permanecen están desprovistas de los paramentos, que debieron ser de sillería (opus cuadrata), a juzgar por algunos sillares remanentes.

La conducción, en canal sobre el terreno, terminaba en el acueducto de Los Milagros, pasando previamente por el desarenador. que es una arqueta de $3,60 \times 3,00$ metros interiores con salida superior en vertedero y desagüe de fondo con cámara de compuertas. Desde esta cámara sale sobre muro en una longitud de $32 \mathrm{~m}$ hasta tomar altura suficiente para elevarse sobre arcadas. Del acueducto quedan los espléndidos restos de tres alineaciones -que luego estudiaremos- y el pilar de ángulo del último quiebro oculto en un patio actual con unos $6,00 \mathrm{~m}$ de altura. La última alineación marcada en la bifurcación de la caja sobre este pilar se debía dirigir a un depósito terminal, como en 
conducción de Proserpina

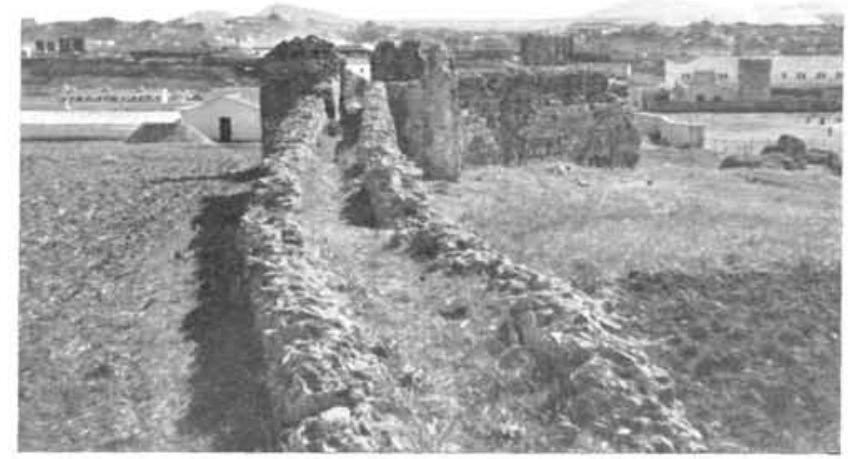

Entrada del canal en el desarenador de cabecera del acueducto de Los Milagros.

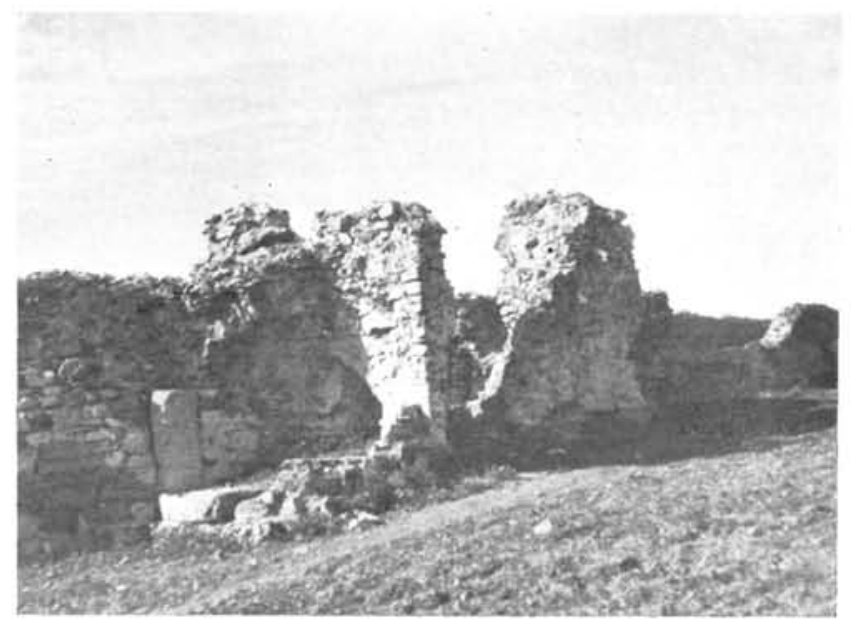

Vista lateral del desarenador con la cámara de limpia anexa.

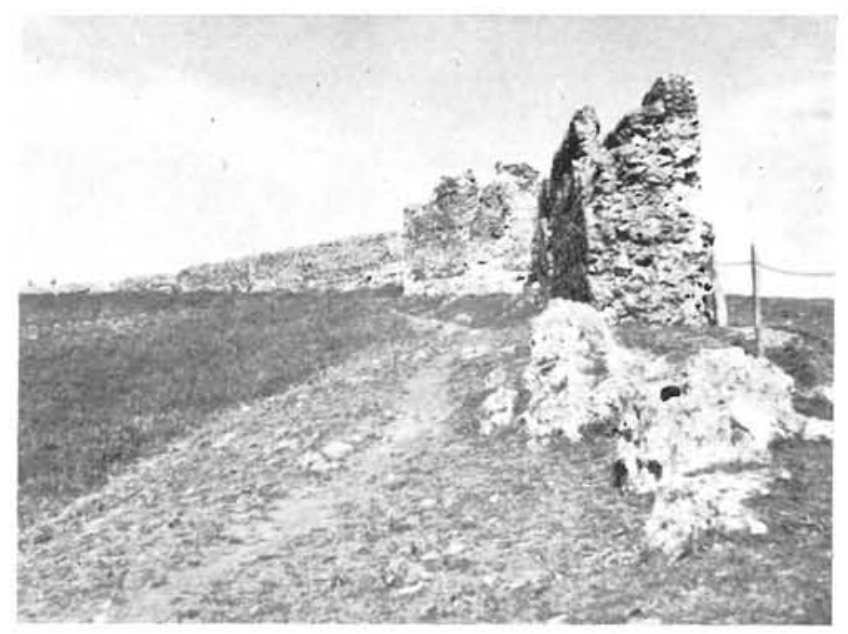

Vista del desarenador y primera zona sobre muro del acueducto de Los Milagros.
Pilar en equilibrio inesta.

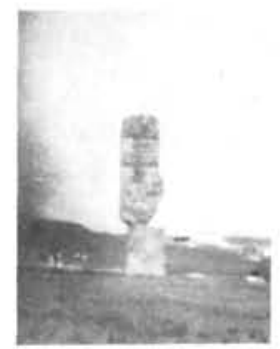

Cornalvo, que nosotros situamos en la explanada existente delante de la ermita de San Jorge, en la que se aprecia la coronación de los cuatro muros que la delimitan. Ya hemos dicho de esta agua que se le asigna una dedicación a fines industriales, que serían mover pequeños molinos situados en casas dentro de la ciudad.

Por las hipótesis de utilización del agua que hemos establecido y por detalles del análisis directo de las fábricas que luego indicaremos, aventuramos una cronología verosímil para las conducciones. Primero, la de Cornalvo, destinada al uso doméstico, que empezó sin el embalse, el cual correspondería a una ampliación posterior. Luego, la de las Tomas, también para ampliar este servicio y dar ocasionalmente agua al anfiteatro y al circo, y, por último, la de Proserpina, destinada a usos industriales.

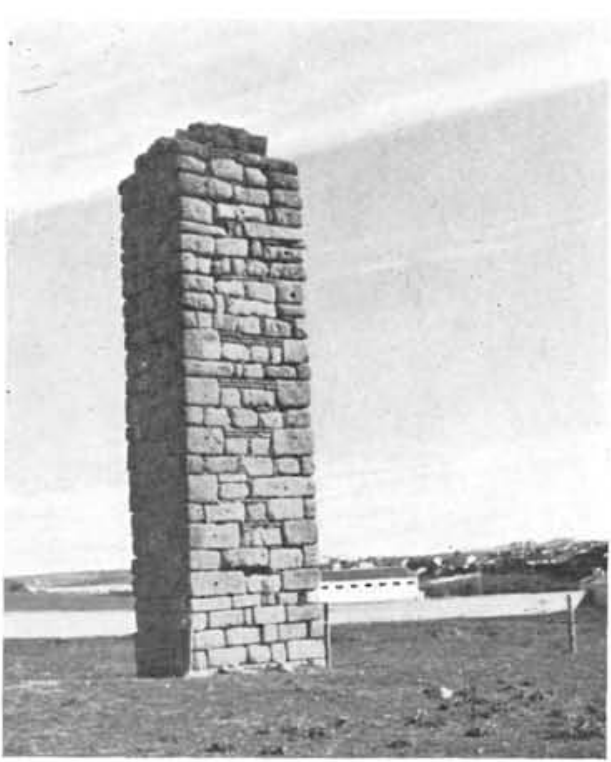

El primero de los pilares subsistentes del acueducto de Los Milagros. 


\section{II descripción de los acueductos}

\section{acueducto de Los Milagros}

El acueducto de Los Milagros se eleva, primero, en muro a partir de un desarenador muy sencillo, al cual llega el canal, también sobre muro, en alineación de $32,00 \mathrm{~m}$, dejando debajo la cámara de las compuertas para desagüe del mismo. La primera alineación de arcadas, que eran sencillas, aparece después de un tramo de muro quebrado con 15,60 y $23,00 \mathrm{~m}$ de longitud, sucesivamente, y en ella se conservan únicamente tres pilares rectangulares, al tercero de los cuales llamaban «el milagro gordo" por la situación en equilibrio inestable de un cuerpo superior apoyándose sobre otro inferior a través de una superficie muy disminuida por la pérdida de sillares en la base del superior. Este pilar se restauró en 1956 y se completaron los sillares que faltaban, asegurando así su estabilidad. Entre el primero y el segundo de los pilares conservados falta otro, y entre el segundo y el tercero, nueve.

Sigue a continuación un intervalo sin vestigios de $123,50 \mathrm{~m}$, en cuyo transcurso el terreno baja lo suficiente para que las primeras arcadas que aparecen sean ya con pilares de contrafuertes, que es el tipo normal. Hay una primera tirada sin pérdida de pilares en $26 \mathrm{~m}$, a distancias oscilando entre 7,30 y $7,55 \mathrm{~m}$, con una longitud total de $178,50 \mathrm{~m}$. Los que ocupan los lugares 9 y 10 en la tirada corresponden al paso del arroyo Albarregas, lo que se acusa al tener su base ensanchada con tajamares por ambos lados, en diedro aguas arriba y plano transversal aguas abajo, siendo además el arco inferior el único de sillería de todo el acueducto. La altura del monumento llega al máximo en esta zona con $28,00 \mathrm{~m}$. La zona de triple arcada comienza a partir del pilar 2 de esta alineación.

Desde el pilar 26 al siguiente se rompe la tirada con $83 \mathrm{~m}$ de longitud sin vestigios, y el primer pilar que encontramos es el de quiebro de alineación, enfilándose en la nueva siete seguidos, a distancias algo más reducidas que oscilan de 6,83 a $7,00 \mathrm{~m}$. La altura varía entre 20 y $15 \mathrm{~m}$, pues estamos ya en la vertiente de la ciudad y la próxima referencia es otro pilar de ángulo —que se ve claramente en uno de los grabados de Laborde y que hoy queda dentro del patio de un taller mecánico- con vestigios de los arranques de los dos arcos que a él acometían, señalando uno la alineación que veníamos siguiendo y el otro la final. A unos $60 \mathrm{~m}$ la caja debía quedar a nivel del terreno junto a la ermita de San Jorge, donde existe una explanada rectangular enmarcada

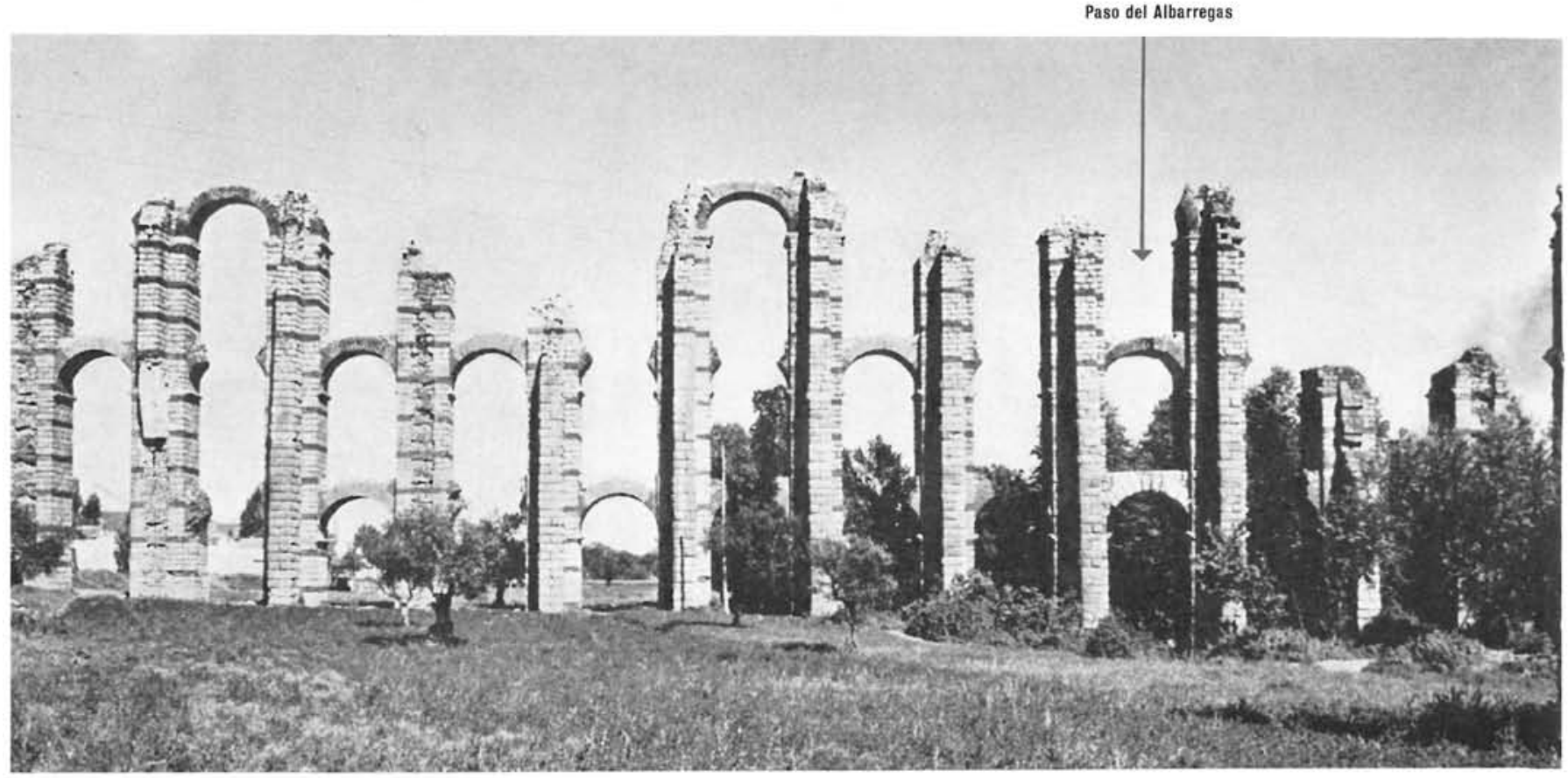

Primera zona de la alineación principal de areadas compuestas: Unicamente la correspondiente a los dos pilares de la izquierda 


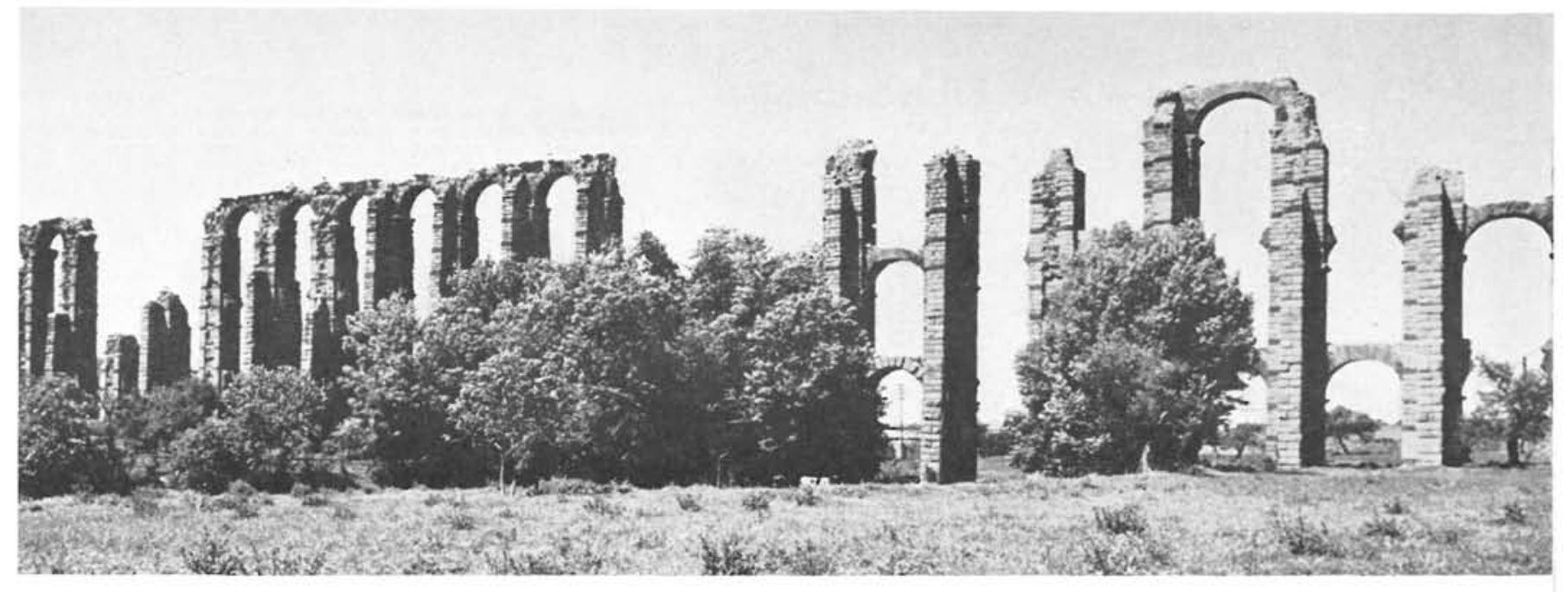

Segunda zona de la alineación principal de arcadas: Se aprecia la bóveda de sillería que corresponde al paso del Albarregas.

por muros que parecen de fábrica romana y que creemos deben corresponder al contorno de una piscina limaria o depósito de agua, que podía estar al descubierto, pues toda la canal lo está y, como hemos dicho, las aguas de esta conducción se destinaban a usos industriales.

En la alineación más importante, paralela a la vía romana, que también cruza el Albarregas mediante puente de la misma época, hay seis pilares, los 13 al 20 en la ordenación general, enlazados todos por arcos superiores, habiéndose perdido en cambio los intermedios. También se enlazan por arcos superiores los de la otra alineación números 27 al 33, pero éstos conservan además los arcos intermedios entre el 22 y el 24.

La sección transversal de los pilares comienza siendo cuadrada $2,50 \times 2,50 \mathrm{~m}$ en el primero de todos los conservados, pero ya el que le sigue tenía contrafuertes longitudinales que reforzaban la misma sección, aunque

Algunas arcadas de la alineación principal: Se puede apreciar la sucesión de cornisas, sillares y fajendos de ladrillo. Obś́rvese la magnitud de los sillares de cornisas y cómo los sillares del núcleo degüellan los contrafuertes en muchas zonas.

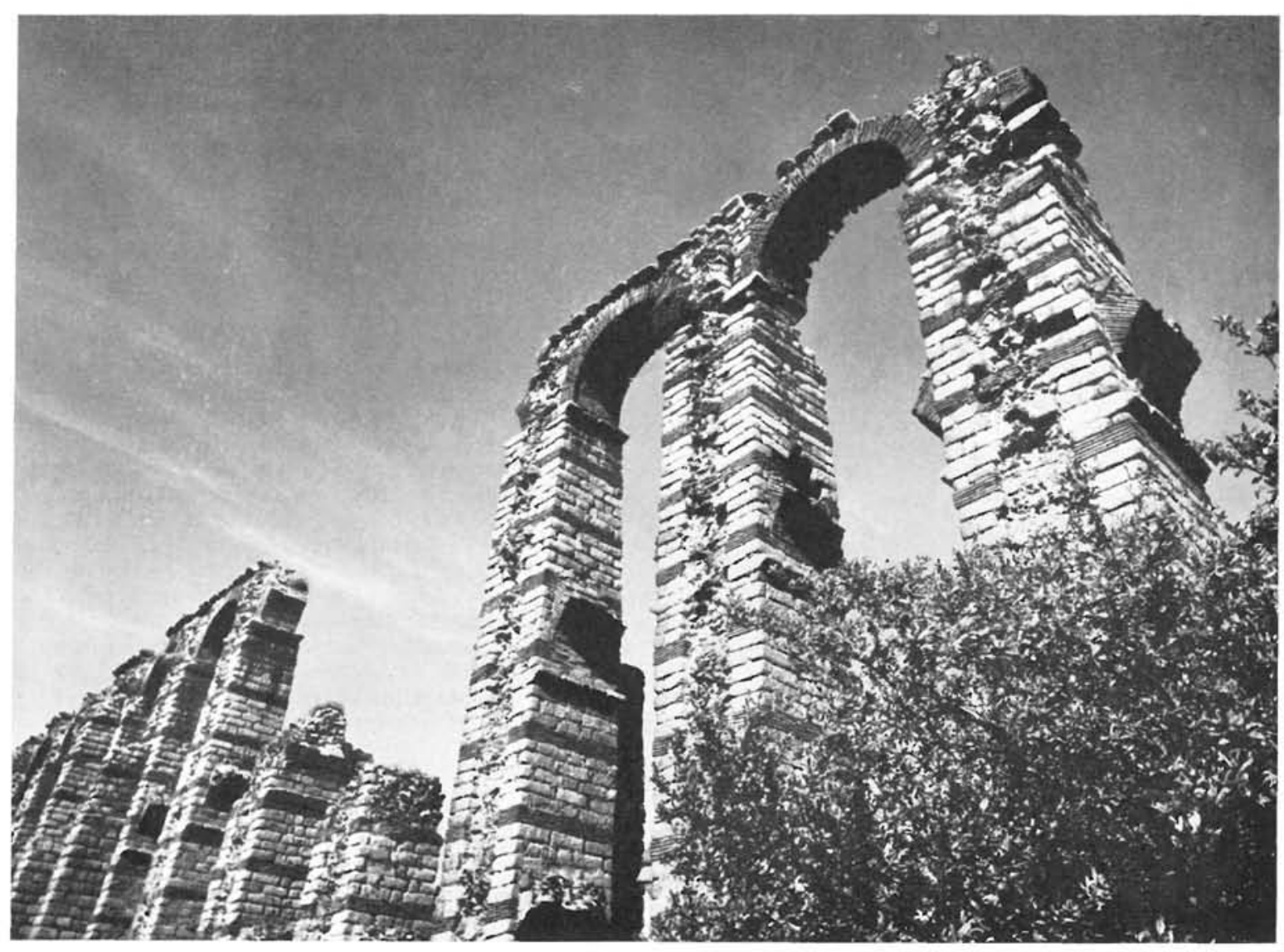



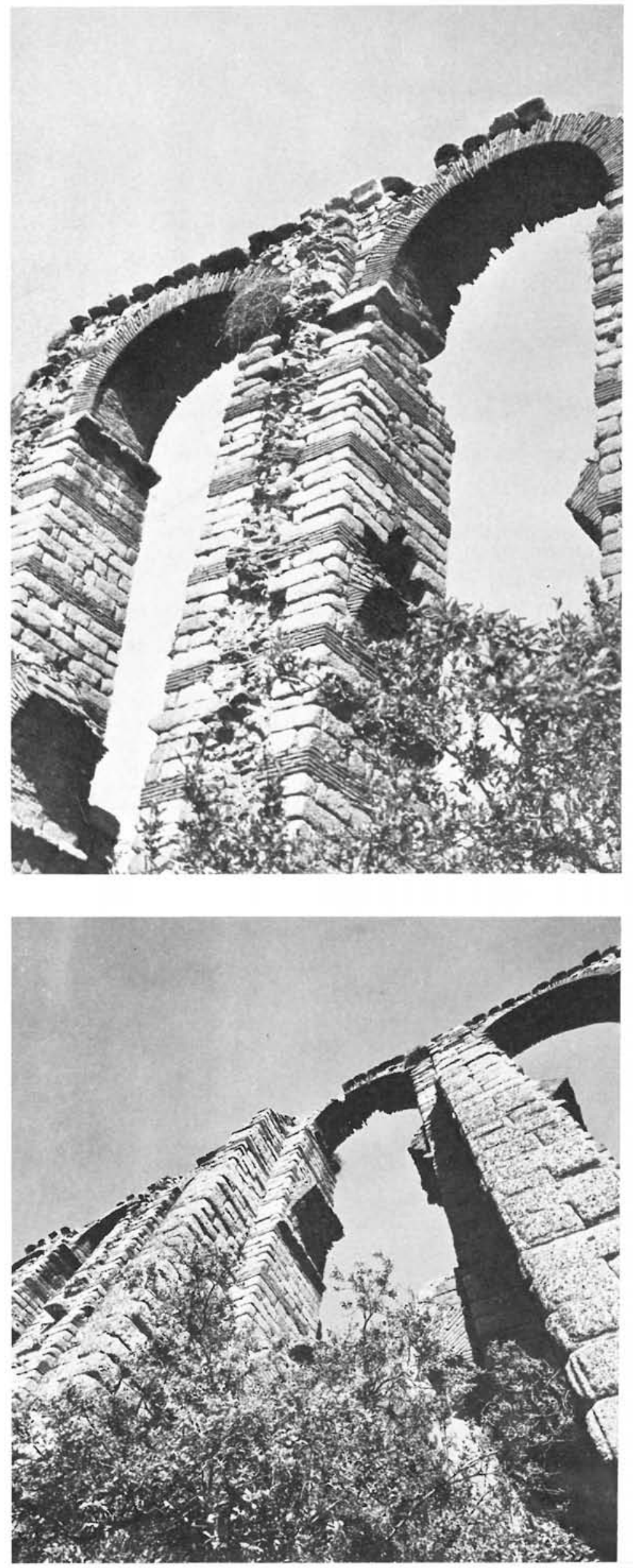

Coronación de los pilares y bóvedas superiores: Se ve la alineación seguida de la cornisa de coronación, los arcos superiores destacados descle arranques y como el contrafuerte debía terminar en prisma triangular. Se aprecia el
salmer de los arranques de las bóvedas intermedias.

no han llegado al presente, y el tercero, además de los contrafuertes longitudinales, tiene otro transversal con 1,50 de ancho y $0,50 \mathrm{de}$ saliente, conservándose en $2,50 \times 2,50 \mathrm{~m}$ la dimensión del núcleo. En estos dos últimos, cuya altura es de unos $15,00 \mathrm{~m}$, aparecen ya las hiladas intermedias de ladrillo.

En los pilares principales la sección del núcleo varía de $2,90 \times 2,90$ a $3,00 \times 3,00 \mathrm{~m}$, es decir, alrededor de $10 \times 10$ pies, al cual se adosan los contrafuertes frontales cuya anchura de 1,30 a 1,38 (debe corresponder a 4,5 pies) con saliente de 2,00 a 2,10 , es decir, 7 pies. La luz es $4,50 \mathrm{~m}$, o sea, 15 pies, salvo excepciones de 4,90 ó 4,65 , y la distancia normal entre ejes es de $7,50 \mathrm{~m}$, o sea, 25 pies.

En el módulo normal de tres pisos el pilar llega sin variación hasta el nivel de arranques de las bóvedas superiores, y allí termina su núcleo, lo cual queda señalado por una cornisa saliente que lo contornea sin pasar a los contrafuertes, cornisa que viene repitiéndose en los arranques de las bóvedas de los otros dos pisos. Los contrafuertes continúan subiendo, aunque reducen su saliente en disminución triangular hasta anularse en la próxima cornisa que señala el nivel superior de las bóvedas y que, de este modo, corría recta a lo largo de todo el monumento. Hasta aquí lo que nos patentizan los restos actuales; después debía venir el cuerpo de coronación con un ático de mayor altura que la correspondiente a la caja, como ocurre en Segovia. En el grabado correspondiente a la reconstitución de Laborde tiene unos $2 \mathrm{~m}$ de altura. En la conducción la canal tiene normalmente $0,30 \times 0,90$, es decir: $2 \times 3$ pies.

Se marcan claramente en los sillares los agujeros para las garras de la tenaza y también las muescas en el contorno inferior para introducir las palancas que permitían trasladarlos en obra hasta su posición definitiva.

Una de las características más notables de los dos acueductos de Mérida es la utilización de la fábrica de ladrillo para las bóvedas y combinada con la sillería para los pilares. En los pilares de Los Milagros se alternan cinco hiladas de sillares con cinco de ladrillo, jugando además con las cornisas de sillería como elementos de articulación entre los distintos órganos de la estructura. Así definen los tres planos de arranques de bóvedas limitadas a los núcleos de pilares y además los planos superior e inferior del ático de coronación, en este segundo tangente a las bóvedas superiores y en el superior definiendo la coronación del monumen-

Vista de una arcada normal incompleta: Se recortan los sillares de la cornisa corrida sobre claves de arcos y puecontrafuertes. 


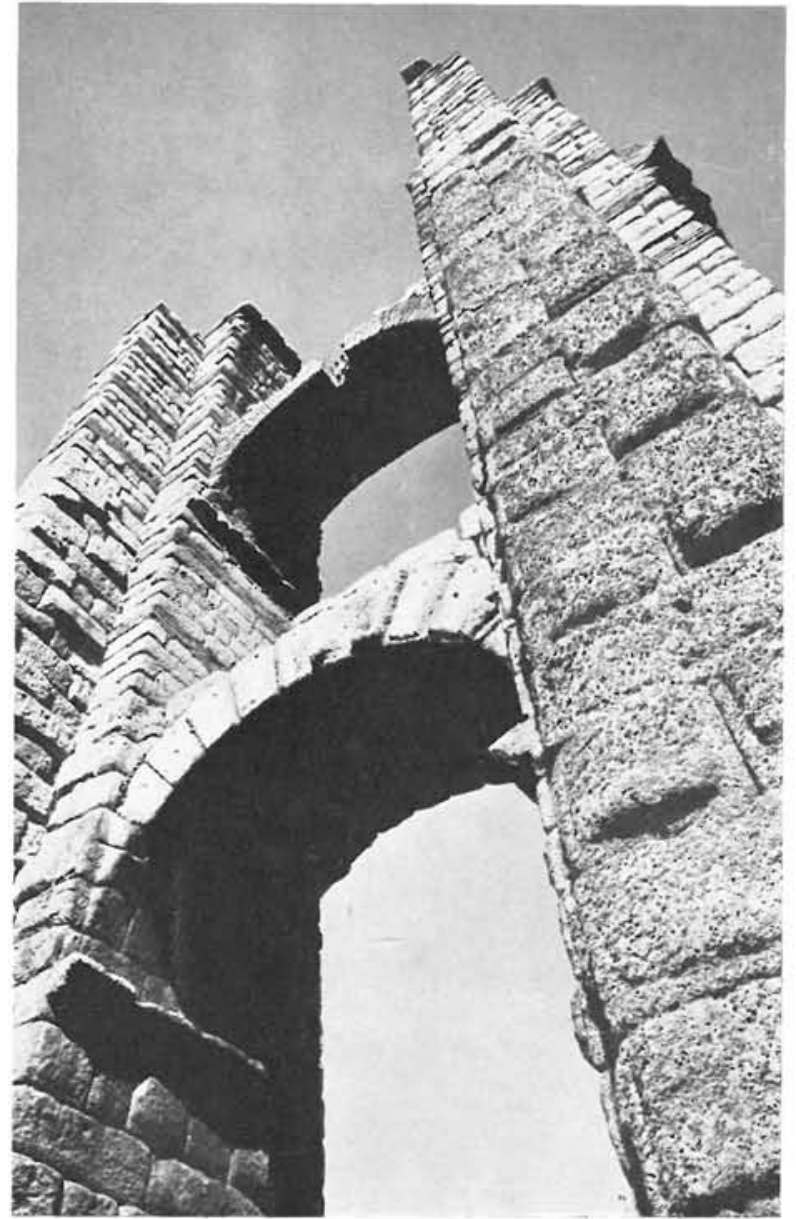

Arcada correspondiente al paso del Albarregas: Con la única bóveda de silleria. Falta la boveda del tercer piso, pero se ve

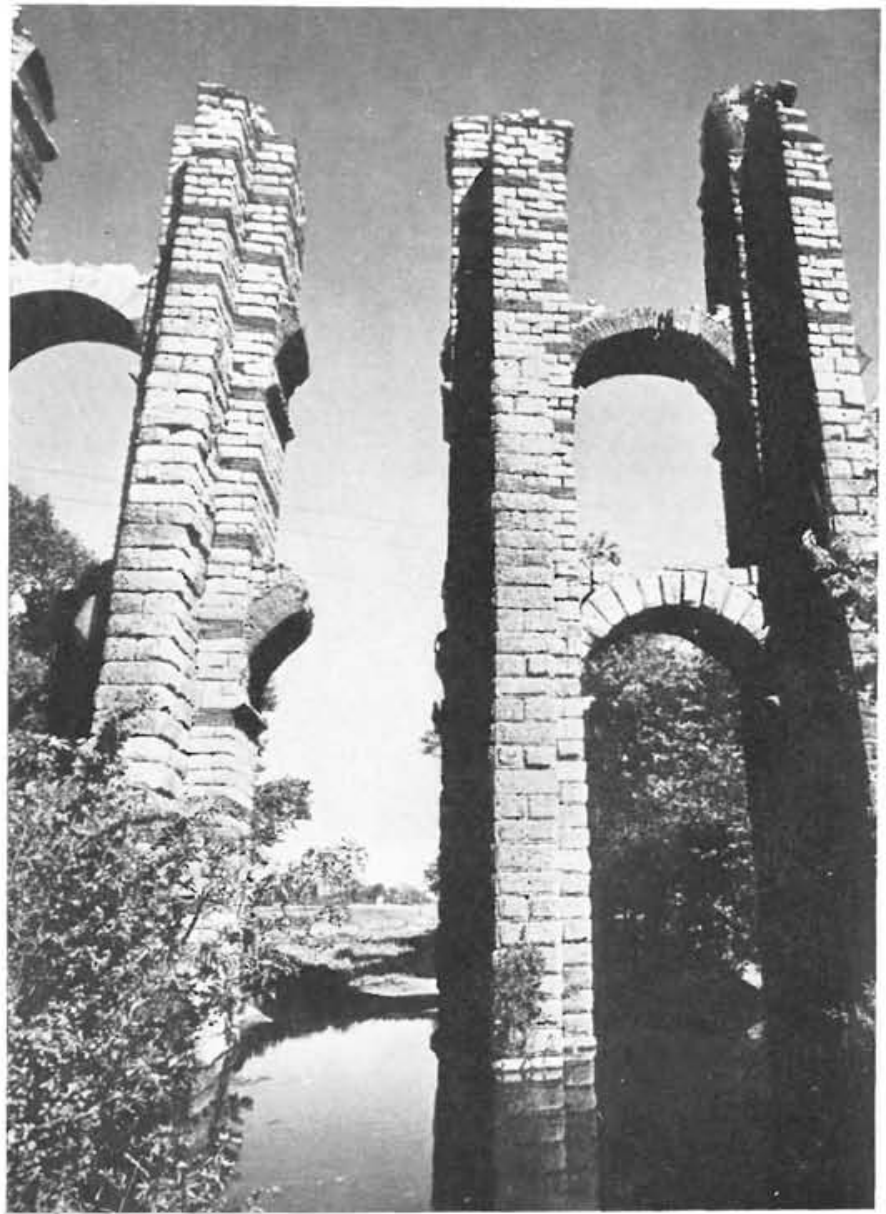

Obsérvese la diferenciación de fábrica de los pilares, especialmente en los contrafuertes a partir del nivel de arranque de los reconstruyó recientemente.

to. Los fajeados de ladrillo se circunscriben también a los núcleos de pilares en los dos cuerpos inferiores, mientras que invaden los contrafuertes en el superior. En los dos cuerpos bajos señalan la altura de claves de bóvedas.

Las bóvedas, a excepción de la inferior en el tramo de paso del Albarregas, son de fábrica de ladrillo, que completa todo el cañón del medio punto solamente en las del piso superior, quedando recortadas por los planos internos de los pilares en los otros dos pisos. De este modo, las bóvedas superiores ostentan las boquillas completas en sus frentes y son verdaderas bóvedas de medio punto, mientras que las de los pisos inferiores son bóvedas rebajadas, pues el despiezo de ladrillos en dirección radial, que indica su modo de trabajar en bóveda, no comienza hasta poderse destacar en todo el espesor de la boquilla, con lo cual quedan sendos triángulos curvilíneos en ambos arranques, que se aparejan como salmeres, primero con ladrillos dispuestos horizontalmente prolongando uno de los fajeados del pilar, y debajo mediante la prolongación de los sillares inmediatos de las dos hiladas adyacentes de la sillería del pilar. No parece existir norma única para el relleno de los semitímpanos de estas bóvedas, ya que en algunos sitios aparece fábrica de ladrillo, en otras mampostería y en otras sillería. Siempre pasa una hilada por encıma de las claves.

En el único arco de sillería tenemos 9 dovelas perfectamente recortadas con juntas radiales a hueso, recercadas y con almohadillado discreto. También se trata de un arco estructuralmente rebajado, disponiéndose los correspondientes salmeres, mediante prolongación de cuatro hiladas de la sillería de los pilares adjuntos. El enjutado de los medios tímpanos laterales se hace prolongando también las hiladas de sillería de los pilares inmediatos. El espesor de las bóvedas es menor que el del núcleo de los pilares, pues sus paramentos se retranquean en medio pie por cada lado. Hay además otra hilada por encima de claves. 
acueducto de Los Milagros

Detalle del arran. que de las bóvedas.

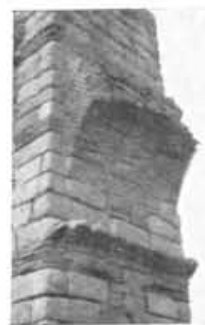

Restos del último pilar de ángulo.
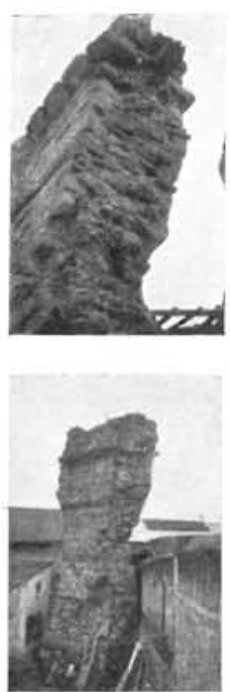

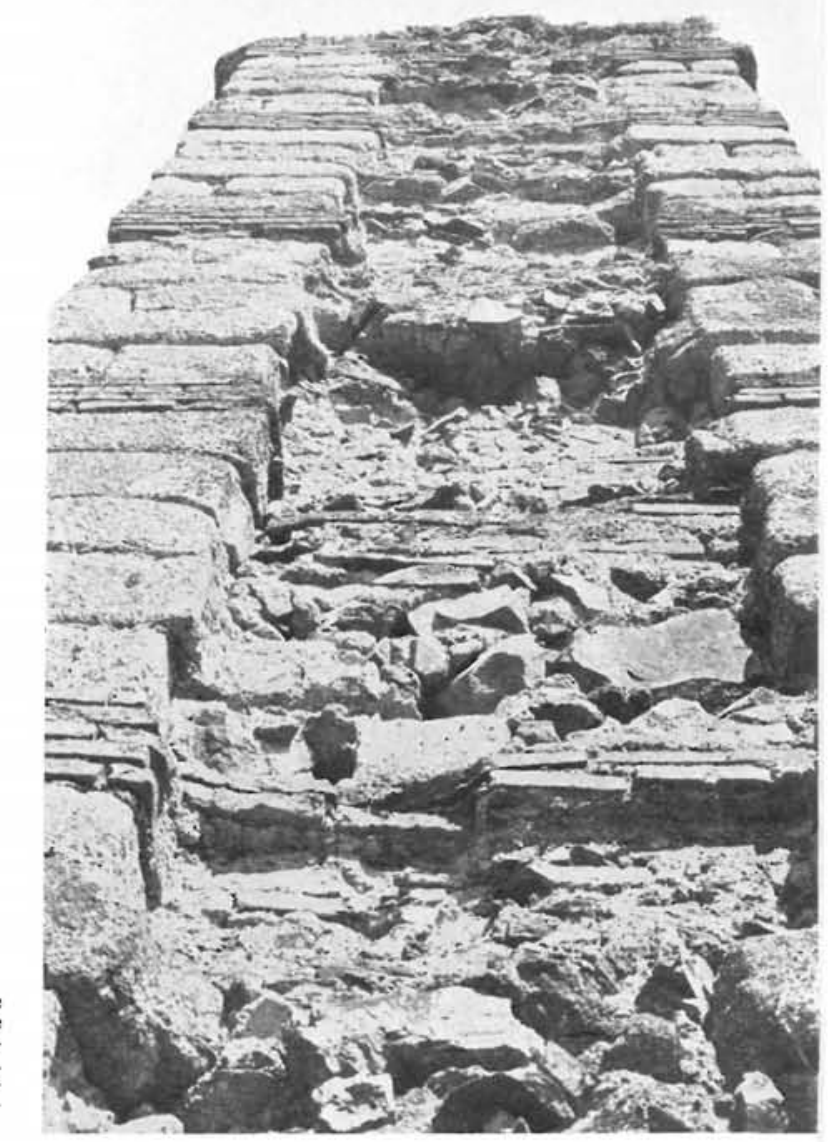
adas de piedra y cinco de ladrillo y como es. tas ultimas cortan la mampos. tería interna del núcleo.

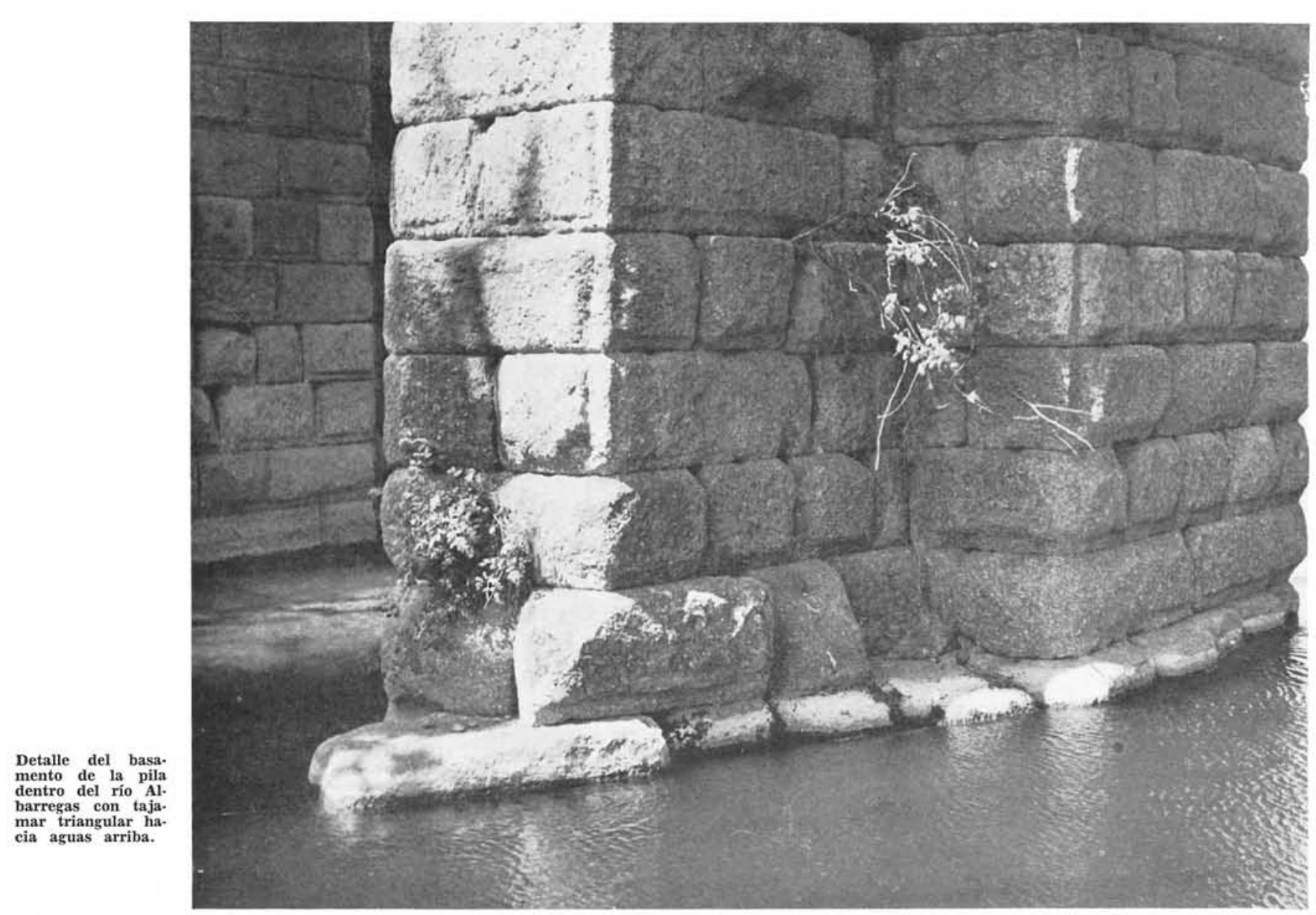




\section{acueducto de San Lázaro}

Las dos arcadas subsistentes de este acueducto corresponden a una alineación intermedia con cambio de dirección en el lado de aguas abajo, y aunque sólo tengamos un pilar normal, el intermedio, podemos deducir la pauta de ordenación del acueducto.

En la ordenación de dos pisos el inferior constituía un basamento de sillería perfectamente destacado en todas sus manifestaciones, sobre el cual se instalaba el segundo piso con pilares y arcos organizados al modo clásico, vigente desde las primeras realizaciones en nuestro país.

Los pilares del basamento son de sección rectangular de $2,50 \times 1,90 \mathrm{~m}$, siendo la primera la dimensión transversal sobresaliente del espesor en bóvedas, que es sólo de 1,80. Estas y sus tímpanos quedan recortados entre los pilares, ya que éstos se elevan con la misma sección hasta el enrase del basamento, terminando en una cornisa a modo de capitel de pilastra por encima de dicho plano. Todos los sillares de este piso tienen un almohadillado muy pronunciado en contraste violento con los del segundo, acentuado esto en los frentes de pilares, con verdaderos picos en los situados a tizón que ostentan su sección cuadrada. Las dovelas no son tan abultadas, pero, en cambio, la de clave avanza en vuelo muy acusado con respecto a las demás. No existe aglomerante entre sus sillares, que tienen unos tizones extraordinarios. Se superponen nueve hiladas sin contar la que corresponde a cornisa, que tiene la misma altura que las demás. Como en el otro acueducto los arranques de la bóveda se obtienen continuando los sillares, que tienen una estereotomía complicada por esta causa, no apareciendo dovelas independientes hasta no destacar el grueso total de boquilla.

En el segundo piso tenemos la combinación de sillería y fábrica de ladrillo, fábrica que se utilizaba en las bóvedas y quizás también en sus tímpanos y en fajas horizontales que atraviesan todo el pilar y aparecen en todas las caras, alternando cuatro hiladas de sillería y cuatro de ladrillo. La planta de estos pilares es cruciforme, inscrita en la rectangular de los pilares inferiores. Se rematan con dos hiladas de sillería formando cornisa la superior a modo de capitel que revuelve en todo el contorno. La luz de los dos únicos vanos conservados es diferente; uno tiene 3,50 y el otro 3,85 metros.

No queda ningún vestigio que permita deducir cómo era la coronación de las arcadas.

Vista de las ruinas desde el lado Mérida: Aparecen tres pilares, dos completos con parte de las bóvedas, y el ter. normal, los otros dos debían ser de ángulo.

Vista de las ruinas desde el lado opuesto a Mérida.
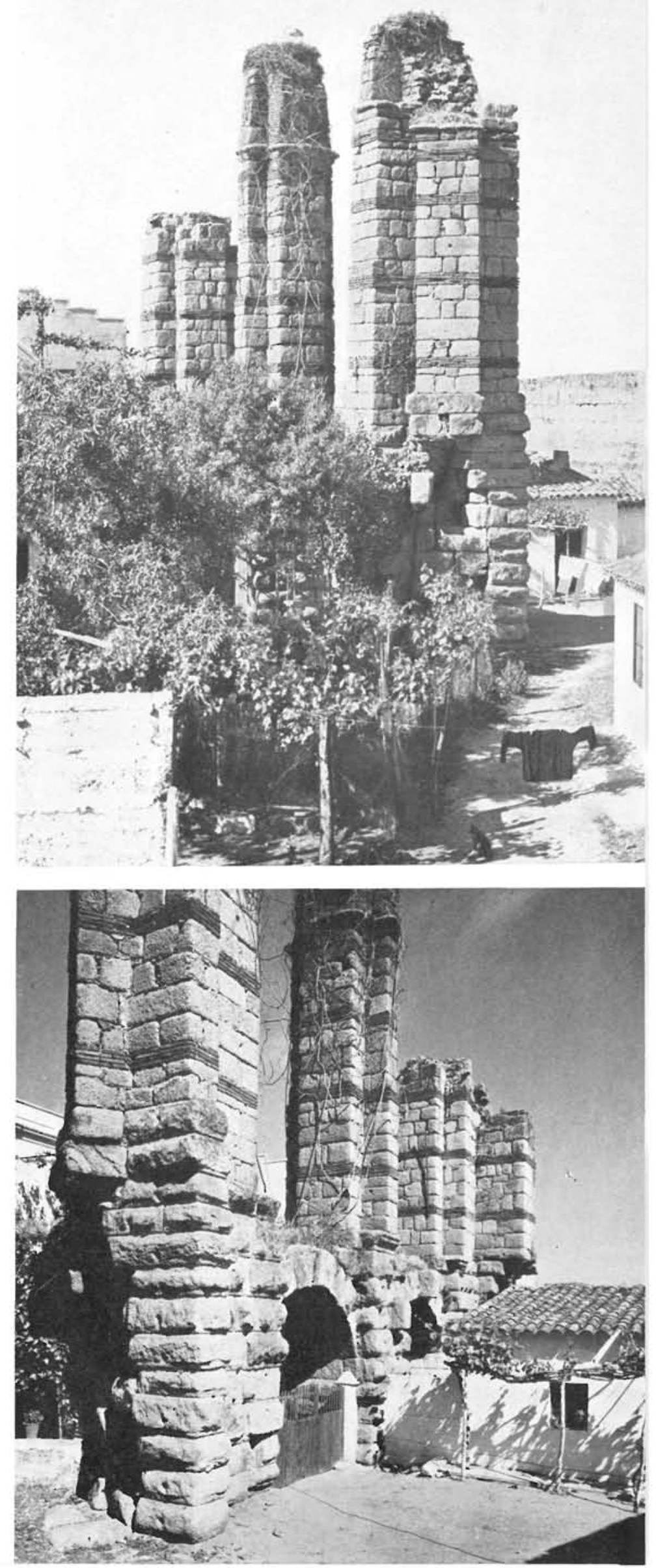

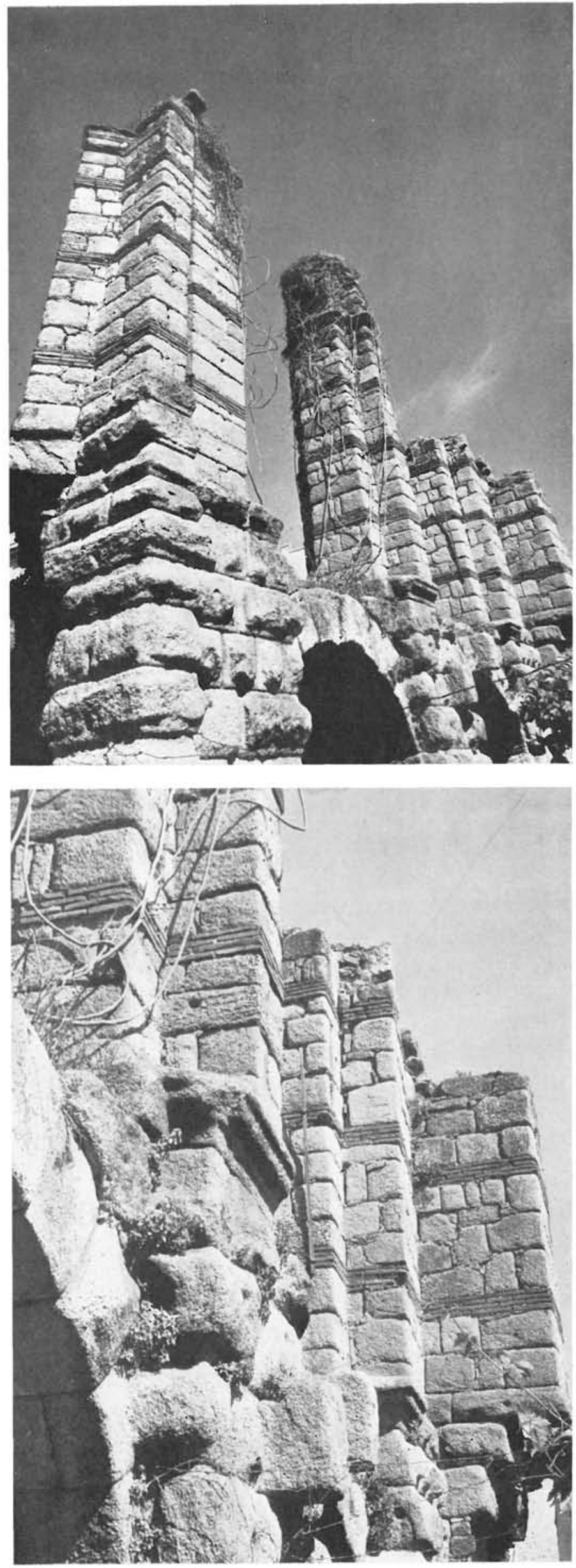

\section{problemas arqueológicos}

Para resolver los problemas arqueológicos que estos acueductos plantean, tenemos la misma falta de puntos de partida que en los demás: ausencia de fuentes epigráficas y literarias romanas; pero ahora es todavía peor, pues tampoco existen referencias posteriores que los atribuyan a un emperador o los encajen en un siglo determinado. Unicamente un criterio restrictivo contrario al que hemos utilizado tanto en Tarragona como en Segovia, nos aconseja excluir el siglo primero para su edificación. Es preciso llegar, por lo menos, al segundo, con Trajano y Adriano, o al tercero, con los Severos.

Nos inclinamos hacia la atribución a Adriano por correlación con el puente de Alconetar. Al estudiar este puente llegamos a la misma atribución verosímil por los detalles arquitectónicos de las pilas tratadas con verdadera exquisitez en planta, llegando a dar curvatura al frente de aguas abajo, perfección pocas veces lograda, que va muy de acuerdo con el empleo de curvas en las plantas de los edificios de la Villa Adriana. Tam. bién va en el mismo sentido la molduración afinada y expresiva en la trabazón y delimitación arquitectónica de $\operatorname{arcos}$ y pilares. El tajamar del frente de aguas arriba, en cuchillo agudo triangular con vértice redondeado, es ya de puente muy evolucionado.

La correlación entre acueductos y puente sigue siendo ostensible en la estereotomía de sus paramentos, en la regularidad de las hiladas, en el almohadillado de los sillares y, especialmente, en la semejanza de la única bóveda de sillería de Los Milagros con los arcos pequeños del puente para avenidas por la margen derecha; pero donde resulta más directa es en la utilización del arco rebajado. Como ya hemos visto en el acueducto se contornea un medio punto en el intradós de los arcos, aunque en realidad se trata de un arco efectivo rebajado aproximadamente a los $2 / 3$, como aparece francamente en Alconetar. Otra correlación con Alconetar es que, si bien en este puente la bóveda es geométrica y estructuralmente rebajada, se marca con moldura el arranque que hubiera correspondido al medio punto.

Unicamente durante la época de TrajanoAdriano se utilizó el arco rebajado. El fenómeno, creemos se debe al ingeniero Apoloduro de Damasco (puente del Danubio y foro de Trajano) y al propio Adriano, quien lo empleó con delectación en plantas y alzados.

Acueducto de San Lázaro: Obsérvese la fábrica descuidada del trozo central del contrafuerte de la derecha, y el 
Otra relación muy notable con la arquitectura adriánea reside en el empleo de las hiladas de ladrillo como trabazón entre los paramentos y el núcleo de hormigón de los pilares, que fue empleada por los romanos desde primeras épocas, y tuvo incluso su designación primitiva: opus vitate-mixta, que es un caso particular de alternancia de fábrica en hiladas completas, combinando en otros casos sillares lisos y sillares almohadillados e incluso llevando la alternancia al adovelado de arcos. Estos artificios son muy frecuentes en la arquitectura de Adriano, como por ejemplo en las fábricas de muros de la Villa Adriana, recortando con hiladas de ladrillo la superficie de la opus reticulatum.

Las razones técnicas de la utilización de estas trabas de ladrillo en la sección transversal de un pilar son, además de esta función de trabazón muy interesante, en especial cuando se utilizan conglomerantes que tardan en tomar consistencia, las de reajustar niveles, corrigiendo los errores acumulados en el empleo de hiladas de sillería de gran espesor, mediante hiladas delgadas de ladrillo en las que se puede jugar con el espesor de llaga para restablecer la horizontalidad.

En el basamento del acueducto de San Lázaro tenemos la impresión de haber pasado ya Alcántara con sus sillares de $60 \mathrm{~cm}$ alternando tizón y soga, aunque aquél mida más del doble que ésta y con el abultamiento excesivo del almohadillado, acentuándose esto en los verdaderos picos que presentan los frentes cuadrados. Las dovelas son más almohadilladas que en Alcántara y más irregulares, y tienen gran afinidad con las de la llamada "alcantarilla romana de Mérida», de época avanzada, pues el cañón, que es de opus lateritiae, se paramenta con boquillas de sillería. Contribuyen a esta expresión barroca de los paramentos la diferencia de latitud en zonas de pilas y bóvedas, lo que da lugar a que los sillares que cabalgan en ambos den una impresión de abultamiento excesivo. También contribuyen a ello las cornisas que marcan los arranques de los arcos y que sólo vuelan en los frentes de pilares.

En contraste con esta sillería de hiladas más regulares, pero con gran abultamiento y recercado según acabamos de indicar, está la fábrica de los pilares del cuerpo alto de las arcadas propiamente dichas, pues la labra es plana y las hiladas, si bien se nivelan con bastante exactitud, tienen alturas diferentes para adaptarse a los fajeados de ladrillo que dan la pauta de horizontalidad. El

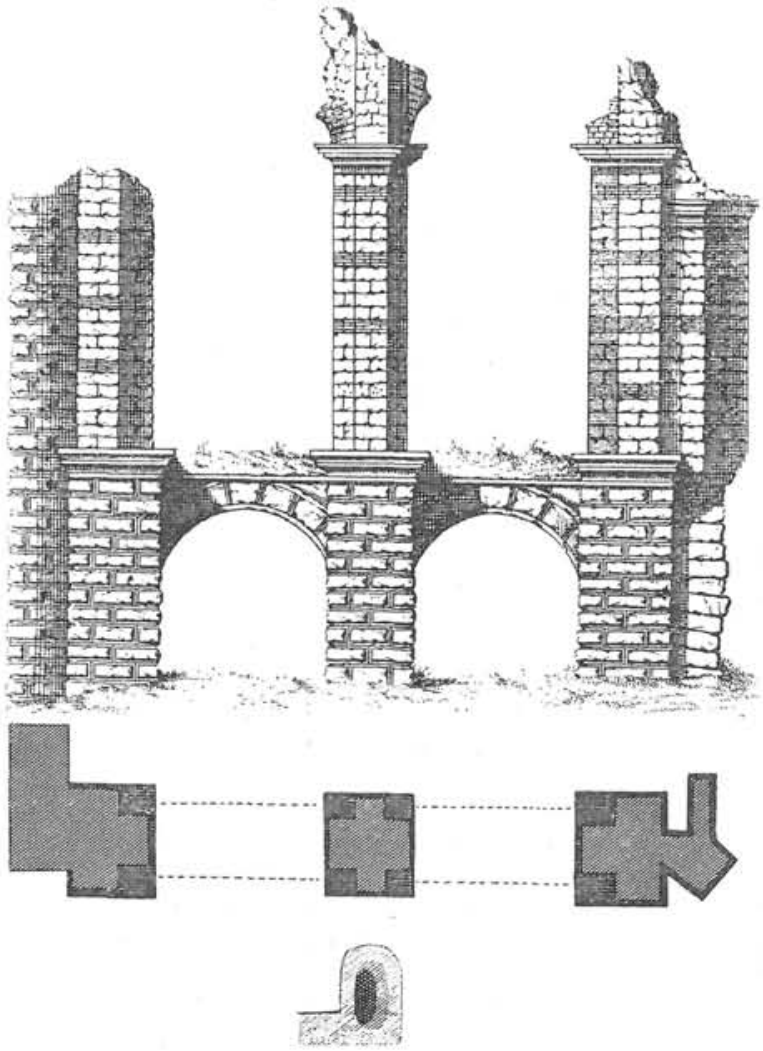

Acueducto de San Lázaro. Dibujo de Ponz [46].

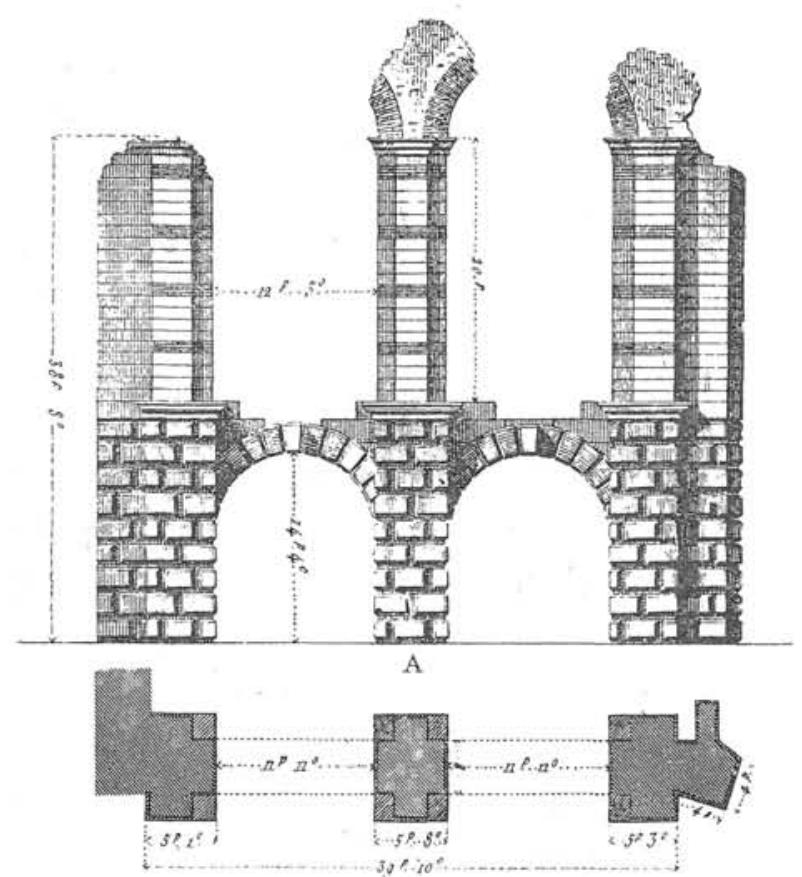

Acueducto de San Lázaro. Dibujo de Laborde [50]. 
patrón de estereotomía no es fijo, si bien en los frentes hay siempre sillares perpiaños, aunque no se suceden con regularidad. Alternan cuatro hiladas de sillería y cuatro de fábrica de ladrillo, excepto en la zona superior, que son tres. Las juntas entre sillares de una misma hilada son normalmente verticales, pero las hay inclinadas y a veces se introduce un relleno de dos piedras superpuestas poco regularizadas o piedras pequeñas rellenando excesos de junta, aunque esto último puede proceder de alguna restauración. Parece que el basamento está sin conglomerante con sillares de gran tizón, y, en cambio, en el segundo piso los pilares tienen núcleo de hormigón, lo cual ocurre también en el puente de Alconetar.

En el acueducto de Los Milagros aparece algo análogo, al diferenciarse en las pilas la zona de dos primeros pisos y la del tercero. La diferencia no es tan marcada porque el almohadillado de los sillares no tiene nunca el abultamiento pronunciado de San Lázaro y además la regularidad de la estereotomía es siempre más lograda. A partir del segundo piso, la sillería es menos cuidada que en la parte baja del pilar, y las caras quedan más lisas sin el desbaste típico de las obras ingenieriles. En los contrafuertes el patrón es siempre 2-1-2-1 en los frentes de la primera zona, pasando a 2-3-2-3 en la segunda. La alternancia sillería-ladrillo eslabona cinco hiladas de una y de otra fábrica. Las de ladrillo hasta el segundo piso se limitan al núcleo, extendiéndose a todo el pilar, núcleo y contrafuertes desde la que corresponde al arranque del arco intermedio, es decir, la que prolonga las cinco hiladas horizontales del salmer.

Los contrafuertes no quedaron bien trabados con el núcleo, pues se han desprendido íntegros, arrancando al desprenderse parte del hormigón de aquél, viéndose que no existe traba directa entre los sillares de paramento de uno y otros, e incluso que algunos sillares del núcleo se prolongan dentro de él, estrangulando la zona de hormigón que los une. En los costados de los contrafuertes el ritmo es 2-3-2-3, correspondiendo las de tres a los perpiaños del frente y las de dos a los isodomos del mismo, estando uno a soga y otro a tizón. Este es siempre más del doble de la soga, con lo cual no coinciden juntas verticales en estos costados. En el núcleo el ritmo es igual por los dos costados, con sillares en número de uno o dos, de los cuales uno se introduce algo dentro. A partir del primer piso el ritmo cambia en el núcleo, pues aparece el de 1-2-1-2 claro y con el tipo de labra más plano la altura de hiladas se reduce y no hay coincidencia con las de contrafuertes. En el interior queda a soga-tizón con bastante regularidad y con ocho sillares como norma.

Según las referencias de El Idrisi en la coronación del acueducto había una galería que permitía el tránsito por su interior, incluso de caballerías cargadas. Pudiera ser que la caja, que de por sí no necesitaba ser mayor que la de la conducción, se llevaba en galería visitable, la cual se utilizaría en la Edad Media como comunicación desde el campo a la ciudad; pero creemos que esto es una fantasía, aunque sí pudo utilizarse, sin cubrir, para el paso de peatones. El ático de coronación del acueducto es más importante que la caja, ya que, como ocurrió en Segovia, se aumentó su apariencia para darle mayor monumentalidad.

En estos acueductos se aprecia la persistencia del empleo de la sillería para la construcción de los acueductos. En Roma hacía muchos años que se había adoptado el ladrillo, que aquí entra en parte mínima y sólo en las zonas donde puede facilitar la construcción, como son las bóvedas y los fajeados para regularizar niveles en pilares. En España tenemos únicamente un acueducto de fábrica de ladrillo (mejor dicho, teníamos, pues se ha derribado en fecha muy reciente), el de Sevilla, popularmente conocido por Los Caños de Carmona, que destaca en todos los grabados antiguos de la ciudad. 

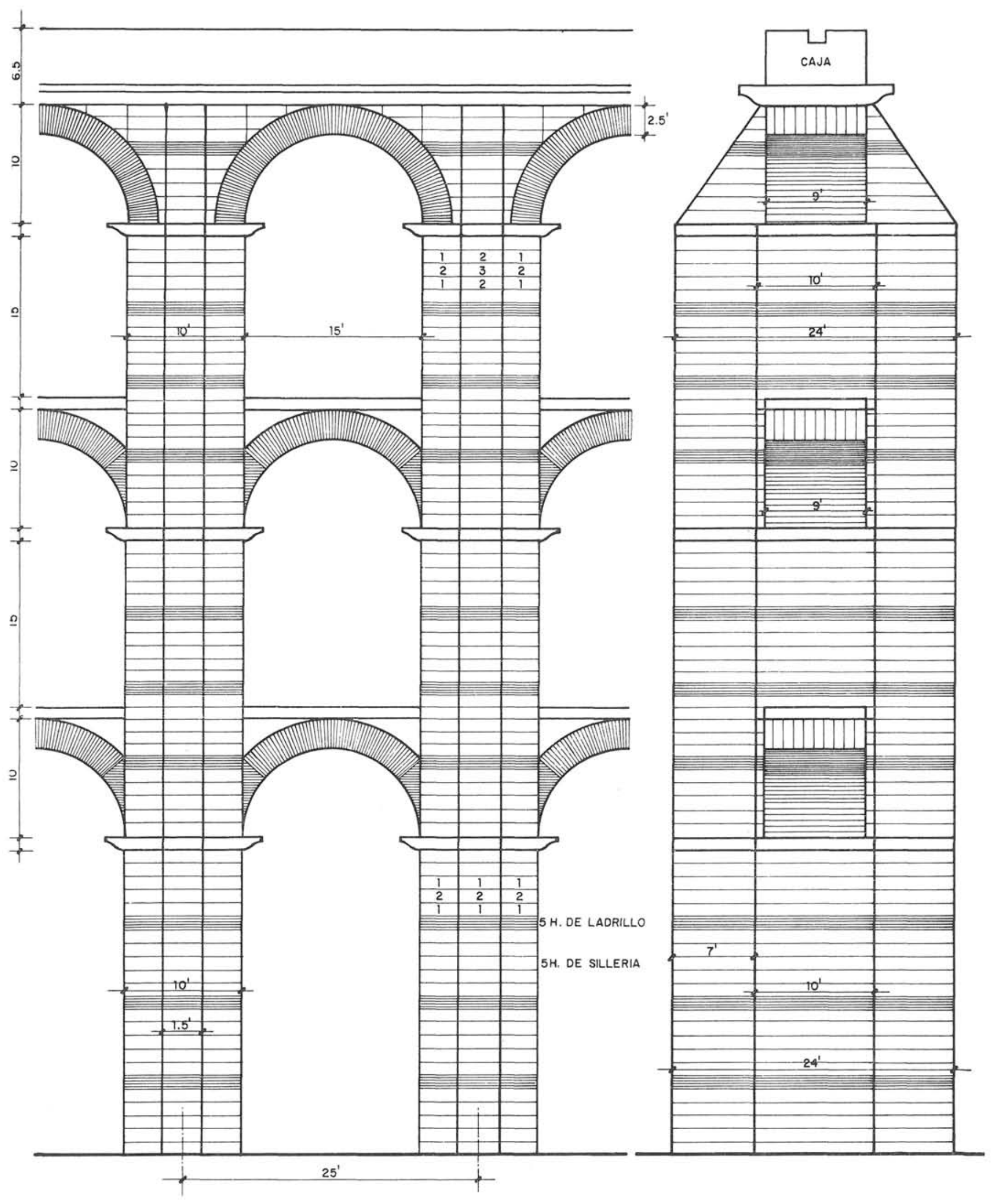

69 

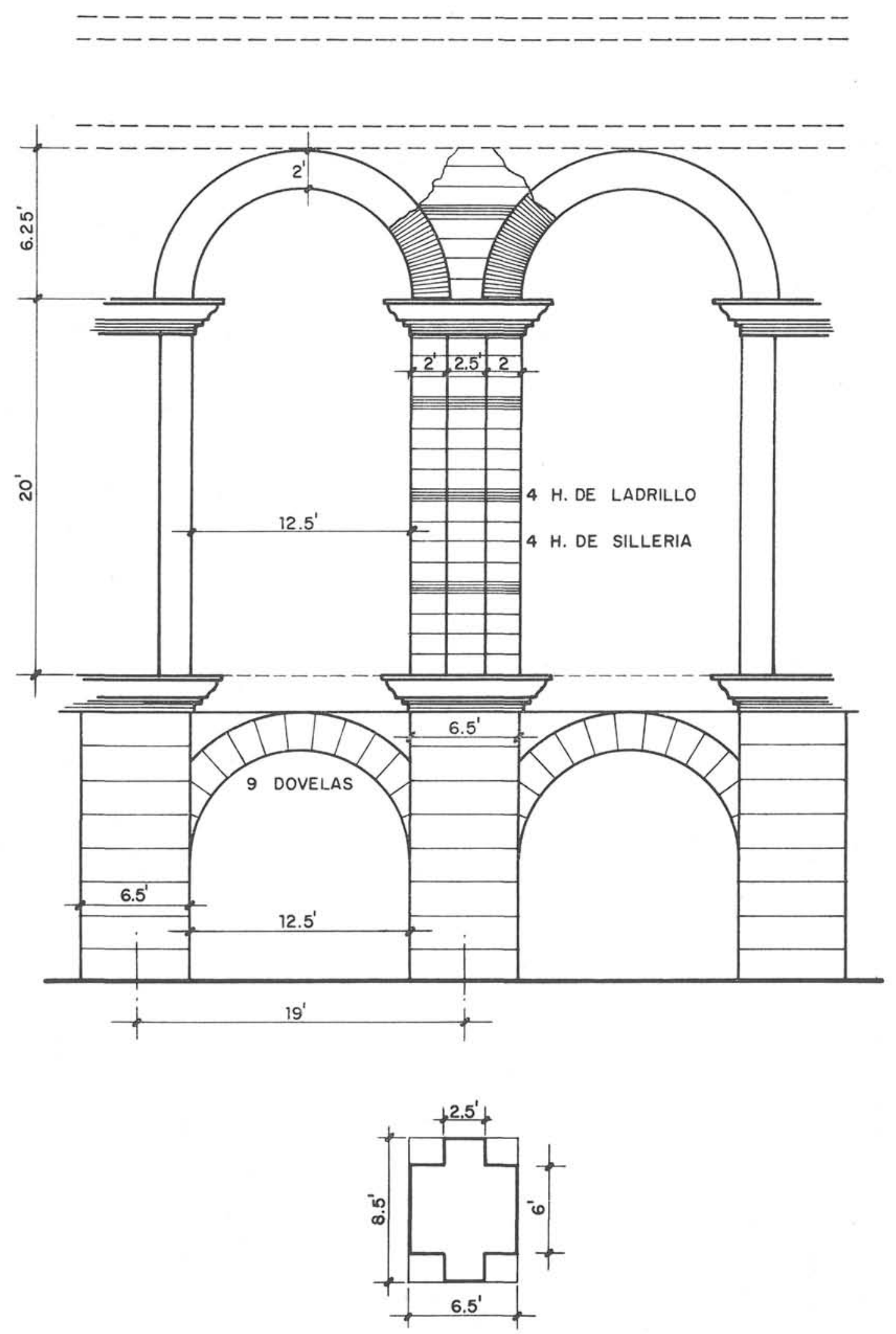


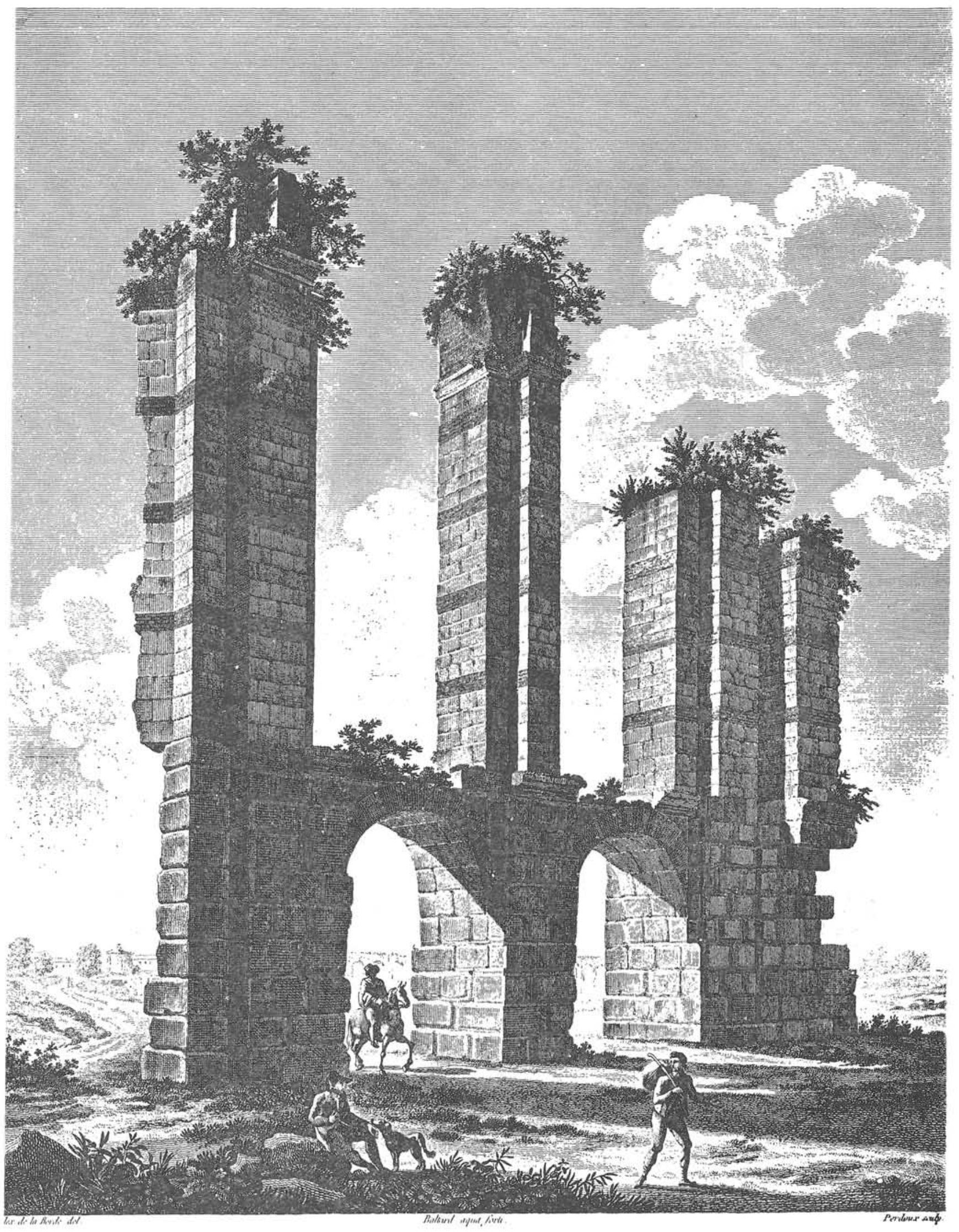

Acueducto de San Lázaro. Dibujo de Laborde [49]. 


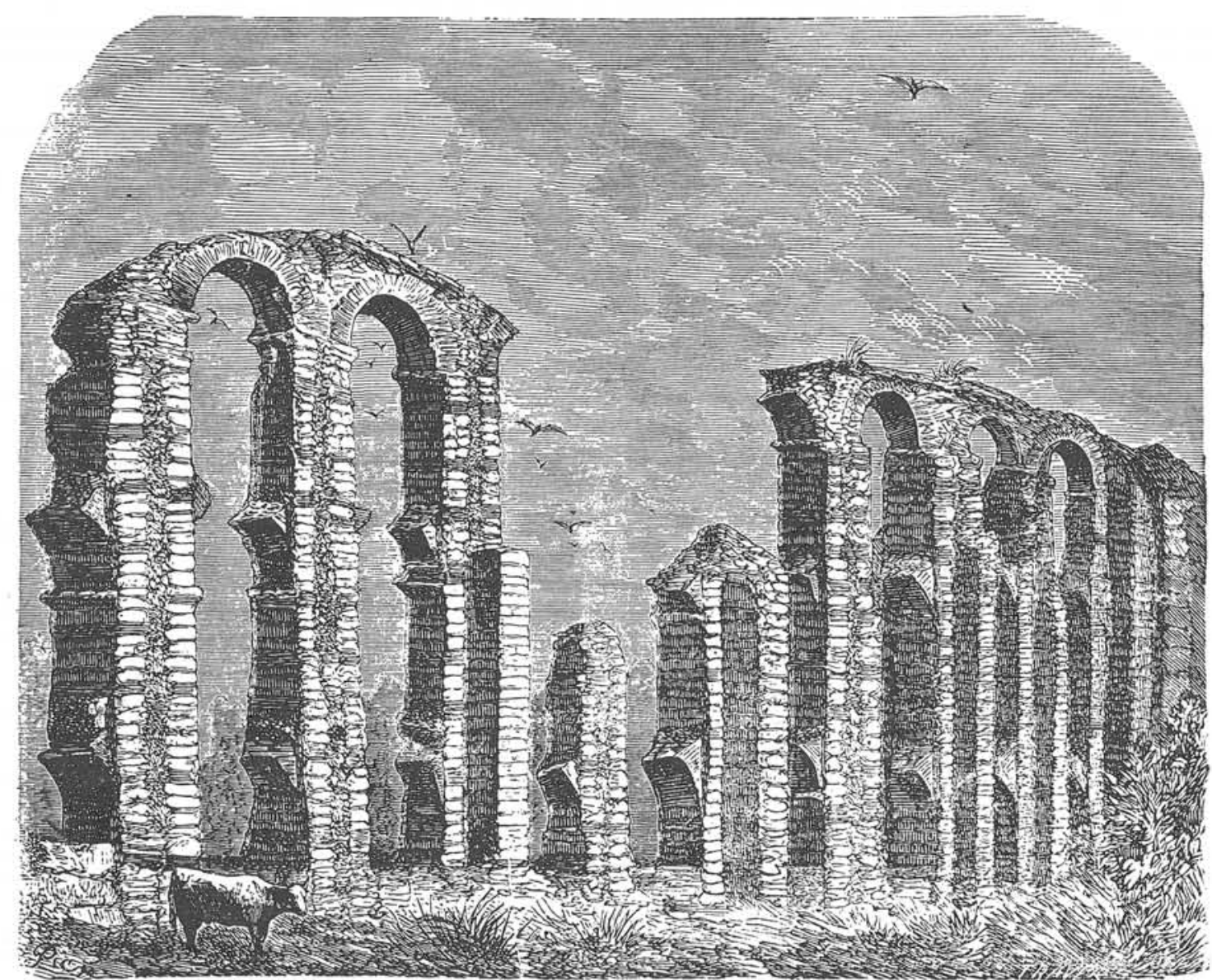

Acueducto de Los Milagros [51].

\section{problemas ingenieriles}

El ingeniero romano frente al problema del acueducto, procedió como el ingeniero actual frente a cualquiera de los problemas de ingeniería de la construcción: por sucesivos avances conseguidos a lo largo de la serie de realizaciones correspondiente; aunque con las limitaciones más angostas, que le impusieron las circunstancias condicionantes de la ingeniería romana.

Estas circunstancias podemos reflejarlas en tres aspectos representativos de la actitud del ingeniero romano: ausencia del ímpetu de dominación de la Naturaleza por sí misma, que se apoderará del ingeniero en los albores del Renacimiento; falta de audacia al tener escasas posibilidades científicas donde fundamentar su hacer, su técnica; y poca intensidad del aguijón de lo económico, que será el principal acicate de la ingeniería actual.

El dominio político es el motor primero que mueve todo el artificio, poco complicado, de la técnica romana, cuyo repertorio de problemas es muy limitado. Uno de éstos, en el sector hidráulico, es el del abastecimiento de aguas a las grandes urbes, y en él puede decirse que llegaron a todas las soluciones que se emplean en la actualidad: embalses de almacenamiento, torres de toma independientes del cuerpo de presa, canal de conducción con sus desmontes, túneles y todas las obras de fábrica del canal, muros, acueductos propiamente dichos, sifones con sus salidas de aire, arquetas de rotura de presión, aliviaderos, desarenadores, depósitos compartimentados, arquetas y red de distribución, e incluso, en cabecera, pequeños trasvases para aportar cauces nuevos al embalse. 


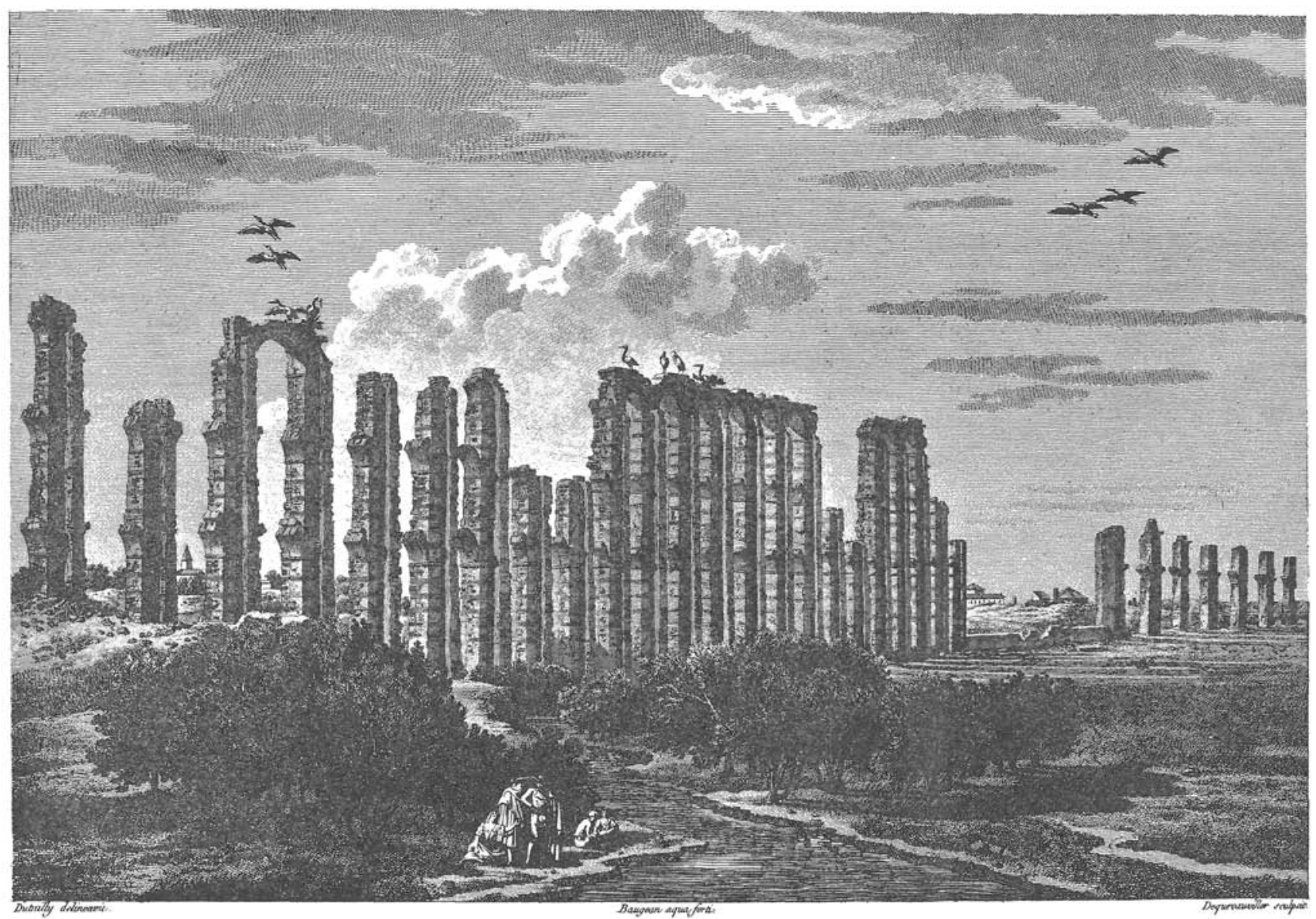

Vista del Aqueducto principal en MERIDA.

Vue du grand Aquéduc à MÉRIDA

Dibujo de Laborde [47]. 


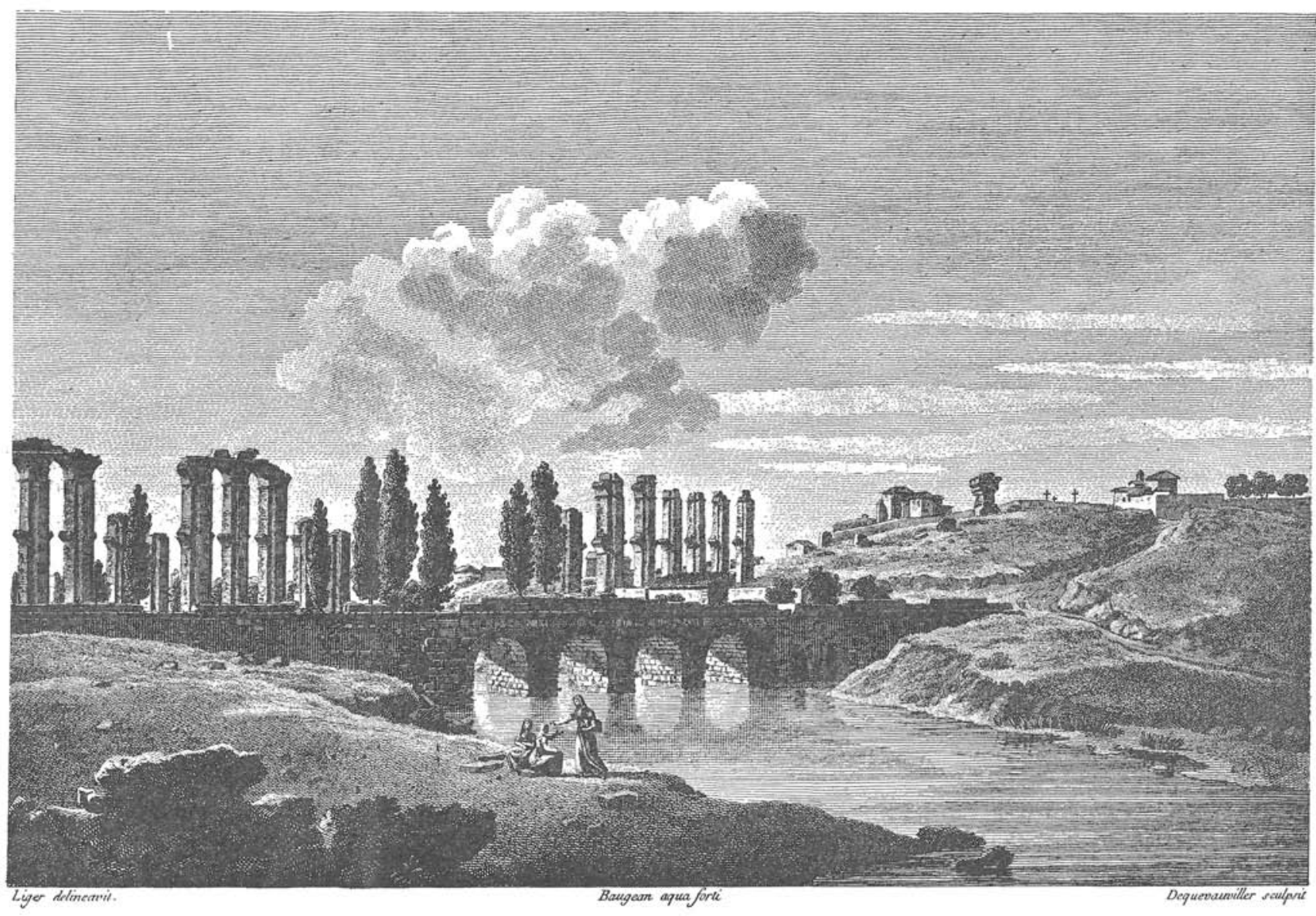

Vista del Puente de ALbaregas.

Vue du Pont d'albarégas 7 View of the Bridge of albaregas.

Dibujo de Laborde [48], 
El caso concreto del acueducto es un ejemplo de limitación de posibilidades y de evolución progresiva hacia un tipo clásico. Como ya hemos indicado anteriormente, hereda las posibilidades constructivas del puente y en cierto modo las expresivas del arco honorífico, pero, al no tener que luchar con el río durante construcción y a lo largo de su vida, su problema se simplifica, ya que la distribución de vanos no viene condicionada por motivos naturales, y se llega a la repetición monótona, con invariancia de luz, que además permanece alrededor de los 5,00 m en todos los acueductos que sean propiamente tales (Pont du Gard y el acueducto desaparecido de Toledo son, en realidad, puentes), luz que viene determinada por facilidad constructiva. Esta luz se halla limitada por dos pilares que se coronan en arco de medio punto, formando la arcada básica, la cual se repetirá ajustándose en cada caso a la máxima altura y a la variabilidad impuesta por las condiciones geométricas del barranco que salva.

La actitud del ingeniero romano ante la Naturaleza cuando va a construir su acueducto es la de imponerle al máximo una regularidad geométrica. Al resolver el problema con alturas cada vez mayores introdujo una variante fundamental a la idea primaria de simples arcadas: la de subdivisión en pisos impuesta por el aumento de esbeltez de sus pilares. Podía haber aumentado luces, que conducirían a mayor sección de pilares y, por consiguiente, reducción directa de esbeltez (no hay que olvidar que el puente de Alcántara, con sus pilares de $50 \mathrm{~m}$ de altura, se corona por encima de todos lós acueductos), pero se decidió por subdividir el pilar, subdividiendo al propio tiempo el ímpetu de la obra, ya que la idea del acueducto de varios pisos responde a la de realizar la obra por etapas, llegando a conquistar niveles sucesivos, para no afrontar directamente la elevación en toda la altura. En origen se trata de superponer un puente sobre otro, pero además consiguen el logro de una nueva regularidad, la del puente superior cuyos pilares conservan su altura en la mayor parte de la longitud que le corresponde.

De acuerdo con esta idea, lo más corriente en los acueductos de varios pisos es limitar los pilares de cada uno entre el nivel de coronación del piso inferior, y el de arranque horizontal de los dos medios puntos que los enlazan, enjutando toda la superficie de tímpanos con hiladas de sillares aplantillados, que se coronan con una en vuelo tangente a las claves de los arcos y que subraya a todo lo largo el nivel de cada piso. Sobre la del último va directamente la caja, o se interpone un ático macizo cuando la caja es de altura reducida.

El acueducto de San Lázaro representa la realización más perfecta de esta idea, como término final de la evolución del tipo. El cuerpo inferior es como un basamento sobre el cual se alza el segundo con diferente tratamiento en los sillares de pilas y diferente fábrica en bóvedas: sillares con relieve muy cuidado, resaltando además la dovela de clave en piso bajo, y fábrica de ladrillo con boquilla total arriba. Una cornisa especialmente cuidada marca la separación de pisos, pero los sillares de los pilares, aunque cortados por la cornisa, se continúan en ambos pisos, desde el inferior, con planta rectangular, al superior, cruciforme, obtenida recortando los ángulos de la inferior. Las enjutas de tímpanos no rompen la continuidad vertical.

En cambio, Los Milagros representa el máximo logro de la otra solución y, en nuestra opinión, la máxima perfección conseguida en el tema acueducto. Precisamente la verticalidad se acentúa donde la subdivisión inicial se ha llevado al máximo romano de tres pisos (en algún acueducto del siglo XIX se ha llegado hasta cuatro pisos). Los pilares arrancan desde el suelo conservando su sección transversal hasta la coronación de las últimas bóvedas, las cuales desarrollan plenamente su medio punto en fábrica de ladrillo con las boquillas totales aparentes, como en el de San Lázaro. En cambio, las bóvedas intermedias, también en fábrica de ladrillo, quedan recortadas por los pilares, y sus boquillas se organizan radialmente sólo en dos tercios del desarrollo correspondiente al medio punto. Quedan, por consiguiente, los arcos intermedios reducidos en su papel estructural a simples arriostramientos de los pilares, aunque esto no hubiera sido necesario dado el cuerpo de los mismos que no hace peligrosa su esbeltez. Como ya hemos resaltado en la descripción de las arcadas intermedias, los pilares prolongan sus tres hiladas, que van sobre el plano de arranque teórico de los medios puntos, para formar salmer que rebaja el arco activo en la proporción de dos tercios, aproximadamente.

Esta variante en el elemento arco, tan encajado en el medio punto, de máxima expresión para el romano por su acabada redondez, la encontramos en ambos acueductos de Mérida y ésta ha sido la razón más poderosa que nos ha llevado a atribuírselos al emperador Adriano, tan devoto del arco rebajado en sus construcciones, especialmente las de la villa Adriana, y nos ha llevado a emparentarlos con el puente de Alconetar, donde el arco rebajado se destaca desnudo, mientras que en los acueductos se enmascara, pues la geometría aparente se conserva, aunque no la estructura expresada por la ordenación de hiladas. Es de recordar que uno de los puentes más notables de la antigüedad fue el construido de madera sobre el Danubio, cuando la conquista de Rumanía por Trajano, por el famoso Apollodoro de Damasco. Este ingeniero, constructor también de puertos, terminó durante el imperio de Adriano y debió haber rivalidad entre ambos en esta esfera de sus actividades, ya que el emperador lo mandó ejecutar. Al emperador Adriano debe Atenas uno de sus acueductos. 


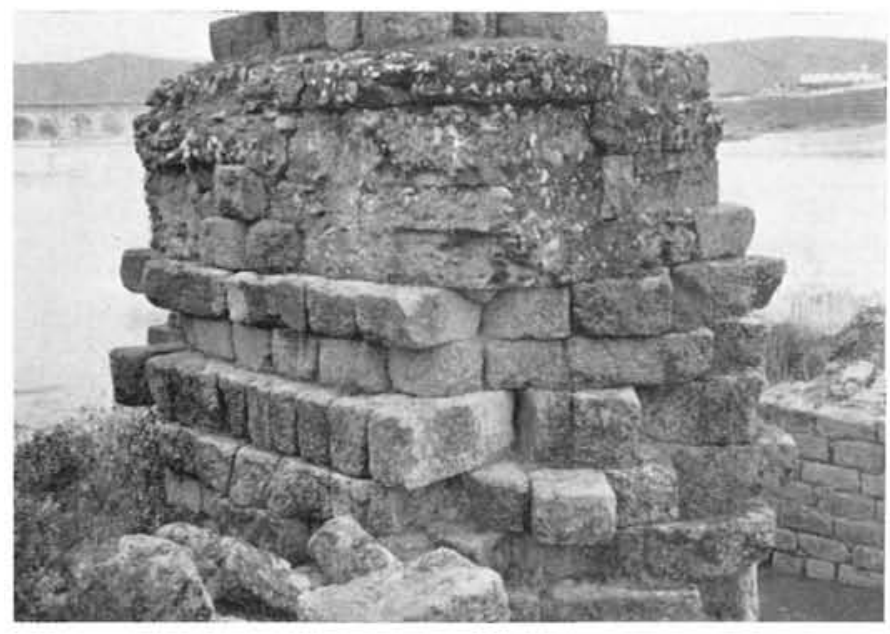

Puente de Alconetar: Al desaparecer los sillares de las caras aparece el hormigón de relleno. Obsérvese el gran tizón de los sillares del tajamar.

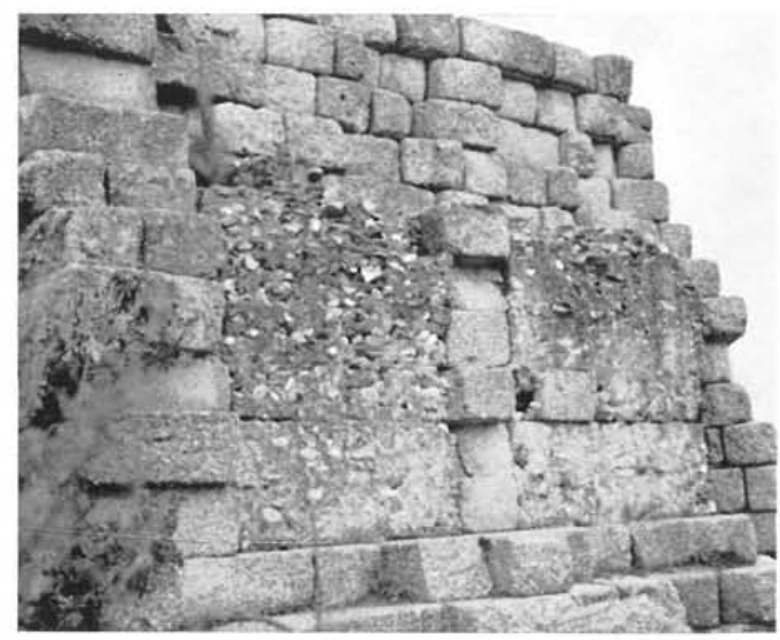

Puente de Alconetar: El corte longitudinal de la pila muestra la traviesa intermedia que enlaza los paramentos y los rellenos de lleria en seco.

\section{problemas estéticos}

Los dos acueductos de Mérida son, como ya hemos establecido, términos finales en la serie evolutiva correspondiente a este tipo constructivo. Sus problemas técnicos están perfectamente dominados tanto en el diseño general como en los detalles y, por consiguiente, en ellos transparece sin limitaciones la intención de sus autores. En sus moles de piedra y ladrillo que cumplen a la perfección su función utilitaria han quedado plasmadas las virtudes del ciudadano romano: la gravitas, la ponderatio, la ordinatio, la aequalitas, la fidelitas, etc. El ingeniero romano podía descansar plenamente en su obra. Es uno de los casos más logrados de armonía entre obra y autor.

Todos los artificios técnicos han ido depurándose para cumplir mejor las funciones hidráulicas, resistentes, etc., pero al mismo tiempo destacando sus posibilidades expresivas, que permiten al que los depura encauzarlas hacia su integración en un organismo que responda además a la necesidad del que construye de expresarse y de consuno expresar su época.

En primer lugar, la regularidad geométrica frente a la irregularidad natural donde se asienta, lograda en la repetición de vanos iguales, coronados por bóvedas idénticas que se sustentan sobre pilares, los cuales han de acomodarse a la desigualdad de alturas. En un segundo logro, nueva regularidad en los pisos superiores al poder ajustar la altura constante de sus pilares, por lo cual se puede componer con toda independencia el tema de las arcadas superiores. Ya hemos visto que en los acueductos españoles tenemos siempre en éstas un contorno interior que recorta en el cielo la figura de un semicírculo sobre un cuadrado.

En todos ellos la situación de los elementos geométricos que tienen papel en el trazado se subraya mediante cornisas que son simples sillares salientes en Tarragona, y se afinan en molduras de talón y listel en los de Mérida.

Pero el logro definitivo del acueducto de Los Milagros es el de volver a la idea pura inicial, unos pilares que se elevan para que, sobre las bóvedas que los enlazan y cierran los vanos, se sustente la caja. Quedan los arcos intermedios en función estructural de apeo, no necesaria como demuestra su conservación hasta nuestros días. Vencen la timidez inicial de construir por etapas, que no era nada romana.

Tenemos un logro particular en este terreno de lo estético de nuestros acueductos emeritenses, al incorporar en su campo realzando su expresión los artificios técnicos correspondientes a la alternancia de fábricas de sillería y ladrillo. Es evidente que el motivo inicial de que las bóvedas sean de ladrillo reside en su facilidad constructiva, y el de los fajeados de la misma fábrica en pilares es rectificar la horizontalidad de las hiladas, pero al integrar todo ello en el conjunto y afinar las proporciones relativas de números, espesores y superficies, queda el artificio elevado a un nivel superior que es el estético.

Esta feliz armonía lograda tuvo trascendencia histórica, pues impresionó a los constructores árabes; y cuando realizan una de sus construcciones más importantes, la Mezquita de Córdoba, la llevan en su imaginación, despertando de nuevo la idea de superposición de pilares y arcos de apeo y la de alternancia de fábricas que aplican en este caso no a los pilares, sino a las bóvedas de los arcos. Pero es curioso anotar cómo en este traspaso de ideas una construcción tan reposadamente estable como el acueducto romano, da paso a una de las construcciones más aquilatadas e inestables que se hayan construido. 


\section{referencias históricas y literarias}

\section{acueductos de Mérida}

\author{
(129) IDRISI: DESCRIPCION DE ESPAÑA (1154). \\ Trad. A. Blázquez. Madrid, 1901.
}

Entre estas construcciones citaremos al $O$. de la ciudad una gran puente-acueducto de gran número de altas arcadas, cuyo tablero ofrece ancho paso. En la fábrica del remate de la obra se ha dispuesto un pasillo abovedado que pasa en comunicación el interior de la ciudad con la extremidad del puente: se puede circular sin ser visto. Por el interior de este túnel abovedado va una tubería que llega hasta la ciudad. Hombres y animales pasan por encima de estas arcadas, que están sólidamente construidas y son de una calidad notable.

\section{(130) AL HIMYARI: LA PENINSULE IBERIQUE AU MOYEN AGE D'APRES LE KITAB AR RAWD AL MITAR. Trad. E. Levy Provençal. Leyden,} 1938, pág. 121.

Había cerca de la puerta, dirección O., 360 arcadas sólidamente construidas cada una de las cuales tenía 50 codos de desarrollo.

(131) IDRISI-AL HIMYARI.-Copiamos la segunda referencia, que es común a ambos, pág. 212 (Después de la descripción de la "casa de la cocina»).

El modo de conducir el agua al palacio era muy curioso: por medio de un acueducto formado por torres de fábrica que se denominan pilas (argatat). Estas, un número muy grande, subsisten todavía, sin haber sido destruidas por el tiempo; mantenidas sobre el suelo en sus basamentos. Unas son bajas; otras, altas, según el nivel del terreno; las más altas pueden tener hasta un tiro de flecha (cien codos según Idrisi); están alineadas en recta. El agua circulaba sobre estas pilas por dentro de conductos construidos al efecto para ello. Estos conductos están hoy arruinados e inútiles, pero los pilares permanecen en pie, dando la impresión al que los mira de ser de una sola pieza, de tal modo están bien aparejados y unidos.

(132) GASPAR BARREIROS: COROGRAFIA DE ALGUNOS LUGARES QUE ESTAN EN UN CAMINO (Viaje de Badajoz hasta Milán, 1542).

Tenían en esta ciudad (Mérida) dos acueductos, de los cuales aún ahora están los arcos enteros en muchas partes de buena y lustrosa arquitectura; uno de ellos traía agua (según algunos dicen) para beber en el verano cuando faltaba la del Guadiana, la cual venía de una alberca que está a una legua poco más o menos de la ciudad donde fue desbaratado y preso Don García de Meneses... Llaman ellos albercas a unos lagos que tienen hechos de las aguas del invierno, con las que mueven en el verano, en los que se recoge grandísima cantidad de agua; es palabra análoga que en nuestra lengua quiere decir lago.

De estos acueductos aparecen muchos arcos levantados junto a la ciudad en el punto del río llamado Albarregas, cuya continuación sigue adelante y queda atrás por los campos, balizada por vestigios de los dichos arcos. Había otros por donde venía agua a dicha ciudad de una fuente que está a media legua de Mérida, en un valle llamado hoy valle de Mari Pérez por el lugar de los cuales viene al presente la misma agua a la plaza por otros acueductos nuevos, puesto que en algunas partes faltan ya los antiguos, bien diferentes unos de los otros, especialmente estando ambos tan próximos, con lo que más claramente se muestra su desigualdad porque en unos hay grandeza de piedras con artificio y majestad de la obra y en los otros ninguna cosa de éstas. Viene esta agua a la plaza a una fuente descubierta que revienta por cuatro o cinco caños, la cual es muy buena; la del río no es tenida comúnmente por tal, y así es de creer porque si no no hicieran los romanos tanto gasto en traer agua de tan lejos teniendo el río en la puerta, puesto que muchas cosas hacían ellos más por grandeza y por nobleza de la tierra que por necesidades de la vida humana.

(133) CEAN-BERMUDEZ: ANTIGÜEDADES ROMANAS DE ESPANA, págs. 385 y 397.

Acueductos.-También son dos y también se asegura que los mandó edificar el mismo emperador. Se descubren las ruinas del primero cerca del puente de $\mathrm{Al}$ barregas; su dirección es del septentrión al mediodía. $\mathrm{Su}$ canal es de 3 pies de ancho, de 3,5 de alto, su mayor grueso no pasa de 11 , y la mayor altura sube a 91, en dos y tres órdenes de arcos, unos sobre otros. El segundo entra en la ciudad por el oriente y venía de muy lejos por el norte, dando vueltas y revueltas. La canal es de 2 pies de ancho, de 4 pulgadas de hondo y de 4 pies y 10 dedos de grueso. Luego que daba vista a la ciudad comenzaba a elevarse sobre grandes arcos, para suplir la desigualdad del terreno hasta muy cerca de la naumaquia, a la que proveía de agua. Perecieron todos sus arcos menos dos, y los nuevos con que quisieron reemplazarlos son de una arquitectura grosera. Este es el acueducto que examinó Pedro Esquivel, en el que echó sus medidas e hizo grandes observaciones para averiguar el tamaño del antiguo pie español. Y fuera también de esta ciudad, como una legua lejos, es también digna de consideración otra obra asimismo romana y particular. Es un fortísimo murallón de piedra y argamasa que tiene 
más de 20 varas de alto y más de 100 de largo, y sirve para contener el agua llovediza y la de los arroyos inmediatos, formando un gran estanque al que llaman Albuhera en Extremadura. En los extremos del murallón hay dos torres que nombra Bocines: tienen escalones para bajar hasta lo profundo del estanque a fin de desaguarle y limpiarle.

Otro murallón y otra albuhera, mayores que las dichas también obras de romanos están en la dehesa de Cornalvo, distante 2 leguas y al oriente de Mérida. Contienen un fuerte torreón y trozos de gradería o asientos en el murallón desde los cuales quizá se verían com bates navales sobre el espacioso estanque como en las naumaquias.

Muy cerca de esta dehesa hay una pradera que, por sus muchos manantiales, llaman del Borbollón, y en la que se descubrieron años pasados varias cañerías subterráneas en comunicación de unas a otras, tan cómodas y espaciosas que puede andar por el interior de ellas un hombre derecho. Es creíble que se construyesen con el objeto de llevar las aguas a esta especie de naumaquia de Cornalvo.

(134) CAMPOMANES: ITINERARIO REAL. Madrid, 1761. Examen de las medidas itinerarias de España $\mathrm{V}$, pág. LXXIII.

Midió Esquivel los intervalos de las arcas, o lumbreras del aqueducto de Mérida y halló había ciento y quarenta lumbreras. Continúa luego Morales dando razón individual de esta medida de Esquivel, así:

«El Maestro Esquivel, mirando estas lumbreras, consideró cómo estaban todas a igual distancia. Pasó adelante imaginando que tendrían aquellas distancias algún número cierto de pies que el artífice les daría. Midió por esto una distancia con cordel, y halló que tenía cincuenta varas justas y lo mismo tenían todas las demás. De aquí entendió cómo en nuestra vara hay algunos pies al justo y ellos forzosamente han de ser tres; pues más, ni menos no les sufre la disconformidad y entendió también cómo el artífice había puesto las lumbreras a ciento y cincuenta pies. $\mathrm{Y}$ de todo resultó saber con certidumbre que un pie antiguo español tenía tercia de nuestra vara castellana al justo, que era ser un poquito menor que el pie romano.n

(135) MIÑANO: DICGIONARIO GEOGRAFICO $182 \%$. Tomo $6 .^{\circ}$, pág. 17.

Los Milagros de Albarregas, restos de un acueducto romano que conducía las aguas a la ciudad para sus fábricas y otros usos.

(136) MORENO DE VARGAS: HISTORIA DE LA GIUDAD DE MERIDA. Mérida, 1663. Capítulo IX: De otros edificios romanos hallados en Mérida, pág. 77.

Muchos son los acueductos, y encañaduras de agua, que en contorno de Mérida se hallan, que venían a la ciudad, de los cuales son muy señalados los dos que pasan por lo alto del río Albarregas, y se reconoce por los fragmentos de sus atenores, que son de sillería y ar. gamasa; traían cantidad de agua del grueso del cuerpo de un hombre. El uno viene encañado desde el valle que llaman de Mari-Pérez, una legua de la ciudad a la parte del septentrión, por un edificio el más célebre que los romanos hicieron en España, como lo testifica el Maestro Esquivel, referido por Ambrosio de Morales (en las Antig. de España, f. 33), que por mandado del señor rey don Felipe II vino a sólo describirle, y halló que debajo de tierra tiene 140 arcas, que los antiguos llamaron castillos, en los cuales el agua se va recogiendo como en esponjas, tomándola de los manantiales profundos que por allí hay, procedidos del agua llovediza que a ellos se trasmina y resume, porque la disposición de la tierra no consiente que corra a otra parte. Tienen estas arcas sus gradas y escalones de piedra por donde se baja a limpiarlas, y la encañadura y acueducto que viene por debajo de tierra es tan ancho y alto que puede muy bien ir por él una persona en pie; de esta manera llega al cerro que llaman Rabo de-Buey, y desde allí venía descubierta hasta llegar a la ciudad sobre altísimas columnas y arcos de admirable y suntuoso edificio, del cual sólo han quedado dos arcos que están junto a la ermita de San Lázaro, y algunos fragmentos del atenor por donde corría el agua, que era de argamasa fraguada de piedras muy pequeñas, más duro y eterno que si fuera de peña, como se ven por los que hay y permanecen hasta ahora en la cerca de don Cristóbal de Contreras Sotomayor, regidor. $\mathrm{Y}$ porque este acueducto romano en lo que estaba descubierto sobre la tierra está del todo acabado por lo haber destruido a mano los godos y moros, se hizo otro por los cristianos, y se fundó sobre muchos y altos arcos hasta llegar a tomar la altura del cerro, donde está la ciudad, en la arca que llaman del contador, adonde se vuelve a entrar debajo de tierra, y el agua se divide hoy en dos partes, una que vuelve a bajar al pilar del Arrabal, y otra que entra en la ciudad por la puerta de Santa Eulalia y va al pilar de la plaza, cuyos residuos se aprovechan y conducen a otros pilares del servicio de las iglesias parroquiales, y otras partes adonde el agua es necesaria, porque es mucha y abundante.

Cría esta agua algún sarro y tova, y por esta causa los atenores del acueducto y encañadura hecha por los cristianos se han ido apretando y cerrando de modo que no dejaban correr toda el agua, y así, para remediar este daño se hizo otra nueva encañería sobre la antigua el año de 1623, por acuerdo de la ciudad, y a su costa e instancia de su gobernador don Antonio de Pazos Figueroa, caballero de la Orden de Santiago, Veinticuatro de Jaén (digno heredero de la noble sangre, valor y rectitud de sus mayores, hijo de don Rodrigo de Pazos Figueroa, oidor de Granada, nieto de Juan Rodríguez de Pazos, que fue hermano mayor de don Antonio de Pazos, presidente de Castilla y obispo de Córdoba), asistió a esta obra, y a la de la fuente que hizo en la plaza, quitando la antigua que en ella estaba, y dejó comenzados los miradores de la Audiencia vieja, que después acabó el gobernador don Diego Hurtado de Mendoza, caballero de la Orden de Santiago, su sucesor; a las cuales obras asistimos don Rodrigo de Cárdenas Portocarrero, é yo Bernabé Moreno de Vargas, como regidores comisarios de ellas. Algunos entienden que el agua que por este acueducto traían los romanos, de la cual hoy se sirve la ciudad en las dos fuentes referidas, entraba en la naumaquia de que habemos hecho mención en el capítulo antecedente, y no es así, porque el haber llegado a aquel sitio fue por tomar altura para desde alli derivarla a las fuentes que entonces tuvieron, por ser agua procedida de limpios manantiales y buena para beber, y no la habían de gastar en la naumaquia, pues para ella tenían otro caño de agua que le entraba por la parte del oriente y venía del sitio que llaman el Borbollón, conducida por las tierras de Ureña, cuyo atenor y caja muestra haber traído muy gran abundancia de agua, de la cual ansí mismo se aprovechaban en el Circo Máximo cuando en él se hacían fiestas navales, como queda dicho, y la que sobraba en la naumaquia pasaba por un sumidero que 
tenía en lo profundo de ella al castillo y almacén de agua que estaba en Guadiana, adonde llaman ahora el Chorrillo, como luego diremos, sirviéndose primero de ella en los baños que tuvieron allí cerca, los cuales duraron hasta el tiempo de los godos y moros, y hoy se conserva con nombre de la calle de los Baños la que allí está, y se han descubierto los rastros de su edificio y de las encañaduras del agua. Y la que venía por el otro acueducto principal y grande, que era para beber, entraba en la ciudad por la puerta principal que ahora llaman de la Villa, por donde hoy ansí mismo entra, y corre por la calle de Santa Eulalia.

El otro acueducto viene desde la Albuhera, de la cual se tratará luego; y para atravesar el río Albarregas, por ser su sitio muy bajo, fue necesario encañarle sobre columnas y arcos de extraña grandeza y suntuosidad notable, pues tienen de altura 32 varas. El edificio es de cantería de piedras de grano y ladrillo, y es tan soberbio e insigne que le llaman Los Milagros, como que su obra fuese milagrosa y semejante a los siete milagros del mundo. Por este acueducto traían el agua del Albuhera, y otras que a él refogían en el camino, y la entraban en la ciudad por lo alto del sitio adonde ahora está el Calvario, en que hay ruinas de la caja o almacén adonde el agua paraba, y desde allí la repartían a los molinos que había dentro en la ciudad, para cuyo ministerio los romanos tenían el Albuhera, y juzgaron era mayor grandeza de su poder que el agua viniese a molerles el trigo a sus casas que no llevarlo casi una legua fuera de la ciudad, adonde está el Albuhera. Ansí mismo el residuo de esta agua servía para batanes, tintoreros y zurradores, porque del mismo acueducto se conoce que era tan copiosa que habia para todo esto y para regar sus jardines.

(137) ANTONIO PONZ: VIAJE DE ESPAÑA. Tomo VIII. Madrid, 1778, pág. 112.

12. Los aquieductos de Mérida no eran inferiores en su grandeza y magnificencia a los de la misma Roma, y lo demuestran claramente sus ruinas No sabemos quántos tendría; pero las mismas ruinas manifiestan que había dos muy principales, y pasaban a la ciudad por encima del río Albarregas, sobre pilares, y arcos cuya dirección era desde la Albuhera, casi una legua distante de la ciudad, y desde una dehesa más al septentrión en igual distancia. Del primero, que tenía su principio en la Albuhera, quedan, si no me engaño, treinta y siete pilares, que llaman vulgarmente Los Milagros, algunos con tres órdenes de arcos unos sobre otros: la mayor altura que se reconoce hoy desde el suelo hasta donde venía el encañado, pasa de treinta varas: dicho encañado era capaz de traer gran copia de agua, pues su ancho es de tres pies, y aún más su alto. La materia de estos edificios, los más célebres según el dictamen del Maestro Esquivel referido por Ambtosio de Morales ${ }^{1}$, de quántos los Romanos hicieron en España, es un fortísimo argamasón, cubierto en 10 exterior con hiladas de ladrillo cocido, y de cantería almohadillada, cuyas piedras son de un tamaño prodigioso.

13. Del otro aquieducto quedan dos arcos junto a la ermita de San Lázaro fuera de la ciudad, y son semejantes en la construcción a los referidos. Salvaba con sus pilares y arcos la hondura por donde corre Albarregas hasta cerca de la naumaquia: pereció la fábrica de este intervalo, que es bastante grande, a excepción de los dos arcos que he dicho. Se ha suplido con otros, que no corresponden en cosa ninguna a los antiguos, pero últimamente sirven de llevar la agua a Mérida $\mathrm{y}$, por consiguiente, es obra utilísima. Parte del antiguo conducto o canal por donde venía el agua se reconoce cerca de Mérida, por anivelar allí el terreno con los arcos; y es menester verlo para creer la fortaleza de su argamasa.

14. En este aquieducto es donde dice Morales citado arriba que el Maestro Esquivel, de orden de Felipe II hizo sus operaciones para examinar el tamaño del verdadero pie español, y halló en su principio ciento y quarenta arcas para recoger el agua de profundos manantiales. Se baxaba a ellas por escalones; y los conductos subterráneos son tales, que un hombre de buena estatura puede caminar por ellos comodísimamente. Hablaré más adelante de esto.

(Entre las páginas 114 y 115 se inserta el grabado correspondiente a los dos arcos del acueducto de San Lázaro.)

(138) JOSE DE VIU: ANTIGÜEDADES DE EXTREMA DURA. Madrid, 1852, págs. 26, 27 y 28.

Muy cerca del último se hallan Los Milagros de Albarregas, obra de la misma época, cuyo nombre da el vulgo a los portentosos pilares que aún se levantan con magestad, restos de un acueducto también romano que conducía de $\mathbf{N}$. a $\mathrm{S}$. el agua a la ciudad: apenas llega cerca de ella se pierde y ya no vuelve a descubrirse, lo cual da a entender que, o Mérida se extendía hasta los actuales vestigios del acueducto, o que desapareció la porción de lo que éste falta: de todos mo dos da a conocer la anchura de su canal, que es de 3 pies, y otros 3 pies y 8 dedos de alto, siendo el mayor grueso de todo el conducto (que es desigual) unos 11 pies. Su materia es argamasa cubierta de cantería y algún ladrillo, llegando su elevación por parages a 91 pies, con dos y tres órdenes de arcos unos sobre otros.

Aún se conservan algunos de los grandes depósitos que surtían de aguas y de delicada pesca a la Ciudad. La llamada actualmente Charca de la Albuhera, antiguamente Lago de Proserpina, a distancia de una legua al N., y la titulada de Cornalvo, eran del número.

El segundo acueducto entra por el oriente, y procede de bastante lejos al N., viniendo a manera de culebra. Su canal es de 2 pies de ancho y 4 de alto, y el grueso del todo son 4 pies y 10 dedos. Apenas daba vista a la población elevábase sobre grandes arcos, que supliendo la desigualdad del terreno por donde corre el río Albarregas, le traían a descansar inmediato a la naumaquia, cuyo depósito alimentaba. Ya no quedan tampoco sino dos de los arcos primitivos, pero arcos que el curioso no se cansa de admirar. Aquí, en este acueducto es en donde ha sido averiguada la casi exactitud del pie romano con el actual de Burgos, pues como hubiese en él 140 arcas o respiraderos por donde los labradores de la inmediata campiña pudieran tomar el agua para beber, y de una a otra mediase una distancia igual, infirió el Maestro Esquivel que estas distancias debían tener una medida fija y determinada. Efectivamente, echado un cordel, halló próximamente 50 varas de una lumbrera a otra, o sea 150 pies.

Los romanos se singularizaron mucho por el aplomo y magestad de sus construcciones; mas en punto a acueductos fueron incomparables, siendo muy de notar que jamás eternizasen sus obras como nosotros, pues lo que empezaban lo concluían, y pronto. Acueductos bien memorables nos dejaron en España, y acueductos grandiosos por todas partes en que podían servir a la comodidad pública. Ocúrrennos en este mo mento varios, y entre ellos el que Augusto mandó fabricar para proporcionar aguas abundantes a una ciudad del Epiro, que le debió, como Emérita, su existen- 
cia, y cuyos monumentos, levantados bajo una misma inspiración $\mathrm{y}$ gusto, tienen igual fecha (unos 22 a 25 años antes de J. C.). Vencedor en Accio, le ocurrió edificar sobre su costa, buen testigo del triunfo, un pueblo cuyo nombre correspondiera a la idea de tan célebre acontecimiento. No bien lo pensó, cuando fue hecho como por encanto; pues surgió de entre aquellas tristes playas la famosa Nicópolis (ciudad de la Vic toria), apareciendo desde luego embellecida con la os tentación de otra Roma, así como nuestra Emérita a propio tiempo; siendo muy de observar también que las medallas que empezaron a acuñarse allí, contienen en su anverso un edificio, torreado, muy semejante al que ostentan en el reverso las Eméritas. Y como Nicó polis necesitase de aguas puras y copiosas, fue traído en poco más de dos años todo un río desde 70 millas (unas 15 leguas) por la cañería más vistosa y sólida que puede imaginarse, a través de barrancos, montañas y precipicios, como es de ver todavía. Dos cosas pasman sobre todo, a los curiosos: la argamasa y consistencia de aquella obra de romanos, rebelde todo aún a los medios comunes de destrucción, $\mathrm{y}$ el delicado nivelamiento de todo el acueducto; en fin, no cabe mayor perfección que la que él revela en medio de su estado ruinoso actual.

\section{(139) A. G. SOMORROSTRO: EL ACUEDUCTO DE} SEGOVIA, pág. 17 .

23. El señor Ponz acompaña a su descripción, y otras particularidades que añade, un dibujo de estos dos arcos, que sin duda eran de los del orden inferior, y tres pilares, de los que en dos se ve el arranque de los arcos y las impostas o cornisas que adornaban la fábrica: hermosísima debía ser ésta y sería cosa muy agradable ver los dos o tres órdenes de estos arcos, que se dilataban por espacio de una legua, pero la materia y forma de su construcción fueron bien diferentes de las del acueducto segoviano, en el que $n$ había en lo interior, ni la hay en el día, argamasa alguna, ni los sillares están almohadillados, ni tienen las fajas de ladrillo, que tan agradáble vista causaban en los acueductos de Mérida. Los pilares tampoco disminuian sus gruesos según se elevaban, como sucede con los del acueducto de Segovia, en donde hay los dos órdenes de arcos. La arquitectura de los de Mérida es exactísima, y no presenta las pequeñas desigualda des que se advierten en algunos sillares, que sobresalen de los demás en el de aquí; y las cornisas que adornan a aquéllos, son en mi juicio más finas y bien acabadas que las del nuestro: pero éste aún permanece, y aquéllos casi enteramente han desaparecido. Mucho hicieron para su destrucción los árabes devastadores, en sus primeros años de la conquista y dominación. También el tiempo destruye mucho; y aunque la construcción y argamasa con que estaban formados los acueductos de Mérida, fuese tan fuerte y dura, como justamente dice el señor Ponz; más dura y más fuerte es la piedra berroqueña y la fábrica sin argamasa, que es como está hecho el acueducto de Segovia. Acaso durarían todavía en todo o en parte, los acueductos de Mérida si hubieran tenido la misma materia y la misma construcción. Si la mano destructora de los árabes no hubiera caído tantas veces sobre la capital de la Lusitania, y ésta hubiera conservado después de su reconquista el alto lugar que ocupó en la dominación romana y gótica, tal vez veríamos todavía los acueductos romanos: pero aún en esto fue tan desgraciada Mérida, porque trasladada su sede metropolitana a Galicia, y reducida a una corta población su inmenso vecindario, no ha podido sostener su antigua grandeza, ni tiene en el día quien pueda sacar de entre los escombros el innumerable cúmulo de grandezas, que en otro tiempo la en noblecieron. Para dar un bosquejo de algunas de ellas, permítaseme insertar aquí una carta, que me dirigió en contestación a algunas ilustraciones que le pedí sobre Mérida el laboriosísimo y curioso coronel de Real Cuerpo de Artillería don Joaquín de Góngora.

26. Acueducto.-Los restos de acueductos romanos no son de menos consideración y magnificencia: subsiste un trozo en dirección del E. a la naumaquia, que parece se componía de dos órdenes de arcos, siendo el primero almohadillado de piedra berroqueña, del que subsisten dos arcos completos; e iguales al parecer; y el segundo orden, de mucha mayor elevación que el primero, es compuesto en sus pilares de hiladas de piedra branca, y de trecho en trecho una faja de ladrillos tan encarnados como el bermellón. Subsisten tres pilares de este orden, y sólo en dos de ellos los arranques de sus arcos, pareciéndome que en la altura total y sus proporciones podrán ser con corta diferencia las que tiene el acueducto de Segovia en el paso que hay desde la carnicería de San Francisco a la puerta de su iglesia.

27. Otros restos de acueducto subsisten al $\mathrm{N}$. de la población, como lo indican una porción de pilares de la misma arquitectura que los anteriores, pero de mayor elevación por el desnivel del terreno. Parece por los arranques de sus arcos que era compuesto de tres órdenes; y en elevación y proporciones serán con corta diferencia las que tiene el acueducto de Segovia a la entrada en la calle de San Antolín; pero no puedo dejar en olvido la agradable vista con que los hermosea la faja de ladrillos sumamente encarnados, que de trecho en trecho hacen parte de los pilares.

(140) G. FERNANDEZ PEREZ: HISTORIA DE LAS ANTIGUUEDADES DE MERIDA. Badajoz, 1857.

Cañería que llaman de Los Milagros: Desde esta charca o gran laguna que en el día surte a un lavadero de lanas y molinos harineros y fecunda una hermosa vega, tomaba el agua la cañería de los romanos, de que voy hablando. En su salida tenía dirección al poniente, y volviendo hacia el mediodía costeaba la sierra que lla man de Carija, en cuyo valle se ve aún el cauce y arcos que allí se formaron: daba vuelta al oriente pasando por la huerta que llaman de la Calera, por donde viene aún en largos trozos sobre la superficie de la tierra, $y$ al fin serpenteando $y$ haciendo una multitud de semicírculos por las faldas de los cerros, que confunden en su dirección, viene a montar la altura de la calzada de Mérida, desde donde corría otra vez hacia el mediodía, para entrar en la ciudad pasando el valle del arroyo Albarregas, sobre los famosos arcos que llaman de Los Milagros. Estos arcos daban principio en la misma altura de la calzada, donde había, y subsiste una grande arca de depósito. Desde allí hasta la bajada al valle, sólo existen aislados tres postes de la cañería pero muchos cimientos y torreones por el suelo. En el valle permanecen aún seguidos veinte y seis postes o pilares, cuya mayor altura es de treinta varas, y todos se trababan entre sí con tres órdenes de arcos, que cuasi todos están quebrados, y sólo se descubren sus principios y arranques. El grueso de cada poste o pilar es de cinco varas en cuadro, y todos estaban reforzados con su estribo por uno y otro lado, que empezando por un macizo de dos varas de ancho y tres de largo o saliente, suben en disminución hasta el último arco o base de la canal. Toda esta obra es de grandes piedras de sillería que forran su argamasa interior, y de recho en trecho hay unas hiladas de cuatro o cinco ladrillos. Después de estos veinte y seis pilares, hay un vacío como de noventa varas, donde no existe pilar alguno, pero luego empiezan otros siete seguidos, que pierden la dirección recta y suben costeando la altura a la ciudad, volviendo un poco a la derecha, y el pri- 
mero de estos postes es más grueso que todos los demás, y a quien el vulgo llama el Milagro gordo; pues como en él hacían empuje y violencia las aguas para volver su inclinación a la derecha, se le dio más consistencia, y cinco frentes para trabar con él la unión de los que declinan de la línea recta. En lo que resta de esta altura hasta la ciudad, no hay más que un poste o trozo de muro que por allí sostenía la cañería y desde él tuerce otra vez ésta hacia la derecha y línea recta al poniente. Este último poste dista del muro romano como unas cuarenta varas y parecía que desde allí iban a entrar ya las aguas en la ciudad; pero haciendo una excavación en el invierno de 1829, por bajo de la ermita del Calvario en el camino que va al puente de Albarregas, aparecieron en el mismo camino a un lado y a otro cimientos de piedras sillares sumamente grandes; y examinados, se vio que eran cimientos de postes de la misma cañería, que se prolongaba aún otras cien varas hacia el poniente en línea recta y paralela con el muro, e iba a desaguar en la ciudad por el costado occidental de la ermita del Calvario; por manera, que en aquel punto del camino formaría la cañería unos arcos de entrada de siete varas de anchura en rectitud, y a cuarenta de distancia de las puertas del muro. En esta cañería observó que trae en todo su curso una dirección tan tortuosa y tomando vueltas por las alturas, que aproximándose en una de ellas a la vista de la ciudad, y pudiendo entrar en ésta sin tanta prolongación, se le hace retroceder y costear por las faldas de otras alturas, antes de llegar a la de la calzada: lo cual se hizo, según entiendo, consultando a la mayor utilidad; pues cuando más terreno y alturas corría, más vegas y casas de campo fecundaba con sus riegos en todas sus líneas. Ella venía toda al descubierto y a la faz de la tierra, exceptuando el paso por los valles donde se construyeron pequeños arcos.

Sobre los últimos arcos de dicha cañería corrían y se ven aún piedras de grano, formando cornisa de media caña que sobresale media vara por uno y otro lado, y sobre la base de esta cornisamenta estaba colocado el gran canal de argamasa por donde iba el agua. Además de la hermosura que presentaba esta cornisa, servía para que pudiesen andar por ella de pie los hombres encargados de limpiar el canal. En el día sirve esta cañería para nidos de ciguieñas, y no sin razón se le denomina Los Milagros de Albarregas, porque parece prodigioso que se conserven estos restos con tanta solidez y firmeza después de dieciocho siglos de existencia. El agua que venía por ella sólo servía para la limpieza y surtido de molinos, fábricas y batanes que habia dentro de la ciudad, como dice Moreno Vargas, y con este fin corría por todo alrededor del muro por un canal que en él había abierto; además de que las diferentes direcciones, y como ramales que al parecer salían de esta cañería en su largo y tortuoso curso, inducen a creer, según he dicho, que se repartía también de esta agua para los riegos, y usos de la población, casas de campo y fábricas que pudiese haber por aquellos sitios.

Otra cañería que dicen de San Lázaro: Esta es la que llaman de San Lázaro, que está frente a la anterior y en línea paralela a la distancia como de mil y cien varas agua arriba del arroyo Albarregas. Esta cañería era más suntuosa que la anterior, y uno de los más célebres edificios que fabricaron los romanos en España y como el fin de ella era surtir del agua que había de beber el pueblo, se construyó con más esmero y hermosura con respecto a su objeto más noble. En el día se surte la ciudad de Mérida de esta misma agua, cuya calidad en sí es excelente, y viene de tres cuartos de legua de distancia, desde el valle que llaman de la Tomas, sito a la parte del $N$. En aquel valle está la primera arca o depósito en que se reúnen las aguas de dos ramales excavados en la tova, o terreno natural: el uno con dirección a $\mathbf{N}$. de más de veinte varas de largo, y el otro con dirección al NO., como de nueve varas, los cuales suministran agua en abundancia, especialmente el último, por el que se filtra más copiosa. En dicha arca da principio un cañón de bóveda subterráneo y bastante profundo con capacidad de poder andar un hombre por él, y de trecho en trecho hay otras arcas que dan luz, y se entra por ellas a limpiarlo. Viene en cauce o cañón haciendo varios semicírculos por terreno bajo y en una distancia de cuatro mil trescientas doce varas en que hay pasantes de cien arcas hasta la altura próxima a la ciudad, que llaman Rabo de-Buey, donde empezaban los arcos de la cañería. Todo este cañón subterráneo es el mismo y en la misma disposición en que lo fabricaron los romanos, quienes le dieron una dirección tan prolongada y circular con el objeto sin duda de que trasmanasen a él y se recogiesen todas las aguas que filtran por su terreno, y que nunca escasean; además de otras que le entraban por otra cañería, que venía a desaguar en él desde los montes de Campomanes, de que hablaré después.

En dicha altura de Rabo-de-Buey y hasta cuyo punto llega el referido cauce o cañón cubierto, hay una grande arca de depósito, y desde ella empezaba a formarse la famosa cañería y soberbios arcos que transmitían el agua al descubierto por cima del valle y arroyo de Albarregas hasta la otra altura de la ciudad donde estaba la naumaquia, y en la distancia de más de mil ochocientas varas. Esta cañería fue destruida por los godos cuando sitiaron la ciudad, dominada por los romanos; y por los restos que de ella han quedado, se conoce lo hermoso y magnífico de su obra. Junto al pilar de San Lázaro existen dos excelentes arcadas de cantería, que llaman Almohadillada, y de una arquitectura igual a las del puente, que tiene cada una cinco varas de ancho, otras cinco de alto y tres de grueso o fondo, y sobre su cornisamenta de media caña se levantan tres postes de ocho o más varas de altura hasta los arranques de los arcos superiores que sostenían el gran canal. Por ellos pasa en el día el camino real de Madrid, y por ellos entraba también en tiempo de los romanos, la calzada o vía militar que venía desde Córdoba, Toledo y la Mancha; por cuya razón, sin duda, debiendo traer por este punto la cañería una línea oblicua, cortando diagonalmente el camino, según lo manifiesta su dirección, para formar más vistosa la entrada se le dio en este sitio una línea recta, y en ella se construyeron los dos arcos con la magestad y hermosura que aún presentan. Por la altura que por estos arcos llevaba la cañería, se conoce que por lo bajo del valle y sitio del arroyo, debió ser más alta que la otra de Los Milagros.

Existen también tendidos por el suelo, y en la línea de esta cañería de San Lázaro, multitud de trozos del canal que había sobre ella, formado de argamasa tan sólida, que ni el tiempo, ni el hierro han podido des. baratarlos. Pasan de cuarenta los que se ven bajando por Rabo-de-Buey a Albarregas; y subiendo desde el pilar de San Lázaro hasta la naumaquia, se cuentan en su línea más de ciento de diferentes tamaños, habiendo muchos de seis a ocho varas de largo, y todos con la canal perfectamente conservada, que tiene tres cuartas de ancho y media vara de alto en su hueco, barnizado todo su interior de argamasa muy fina con moldes de media caña en los costados del centro. Esta cañería termina con dirección a la naumaquia, donde efectivamente entraba, y se valían de ella cuando se necesitaba llenar el baño o estanque; pero su uso común era el de surtir las fuentes, para lo cual se separaba un ramal, que se descubre en un trozo de cañería romana que se ve aún con dirección al pueblo, contigua y en la misma línea que trae la que surte en el día; pues para suplir la falta de la antigua se fabricó otra 
moderna, que tomando el agua en el arca o depósito en que concluye el cauce romano en la dicha altura de Rabo-de-Buey, la conduce por atanores hasta la altura de enfrente que domina la ciudad. Esta cañería mo derna es de mampostería; no tiene la altura de la romana, y aunque obra ordinaria, y con remiendos, es de mucha utilidad.

Tercera cañería que venía del Borbollón: Hay otra tercera cañería que venía del Borbollón. Es el Borbollón un fuente o gran manantío que hay sobre las alturas de los montes que llaman de Campomanes, dis tantes dos leguas de Mérida hacia la parte de oriente, donde tomaba el agua esta cañería, que viene subte rránea, y se ven aún descubiertas algunas de sus arcas, por donde se baja, en bastante profundidad, al cañón formado de piedras, igual al que he referido en la cañería anterior. En algunos parages, o sitios bajos, sobresale la cañería a la faz de la tierra, y en otros, como en Caño Quebrado, y el caño que llaman de las Vicarías, existen rotos los arcos, y muro de la misma cañería; la cual se presenta también al descubierto, y sobresale un poco de la tierra al acercarse a Mérida como a doscientos pasos del muro, trayendo una dirección recta a la naumaquia, donde entraba por la parte del mediodía. Como esta cañería viene por las alturas que dominan a la ciudad, y no tiene que vencer valle alguno para acercarse a ella, no hubo necesidad de formar arcos como en las anteriores: entra subterránea en el muro; y en las diferentes vueltas y círculos que forma en su curso, camina más de tres leguas de tierra, en cuya larga distancia no sería extraño que surtiese de aguas a otros pueblos, casas de campo y hermosas posesiones que habría en un suelo tan a propósito como el que coge su línea todo al oriente de Mérida. En el día está obstruida y sin uso; mas como siempre recibe alguna agua en su madre, y subsiste el cauce, o conducto subterráneo, podría suceder muy bien que por muy ciego que esté de tierra y broza, se filtre y se comunique por él parte de la misma agua que produzcan los veneros y manantíos que se encuentran por todo aquel terreno, y que sea cierto lo que algunas gentes dicen, que el agua del pilar de la dehesa de Albarregas es filtración de esta cañería. Contiguo a una fuente que hay en dicha dehesa se ven fundamentos muy sólidos de argamasa, que demuestran no haber sido de poca consideración el edificio que sostenían. El abandono con que hoy se miran estas obras, es mayor que el empeño y celo de los romanos en fabricarlas.

(Tiene dos láminas, una con inscripciones y en la segunda aparece además del teatro y del anfiteatro la "Cañería moderna que llaman de San Lázaro, sustituida a la antigua de los romanos») )

\section{dibujos}

[46] PONZ. Madrid, 1778. Dibujo de los dos arcos supervivientes del acueducto de San Lázaro inserto entre las páginas 114 y 115 del tomo VIII, encuadrado y con el número 114 en paginación.

[47] LABORDE: Vista del aqueducto principal en Mé rida. Las referencias al pie son: Dutrully delinea vit, Baugean aqua forti y Dequevauviller sculpsit.

[48] Vista del puente de Albarregas. Aparece en segundo término parte del acueducto de Los Mila gros y especialmente a la derecha en el horizonte la ermita de San Jorge con su Calvario, en cuya explanada debe estar enterrado el depósito ter minal. Junto a ella el pilar de quiebro para la última alineación que conducía hasta dicho depó sito. Las indicaciones al pie son: Liger delineavit, Baugean aqua forti y Dequevauviller sculpsit.

[49] Vista de una parte de los aqueductos en Mérida. Las indicaciones que constan, además del título, ambién en francés y en inglés, son: Alex de la Borde del, en el centro; Baltard aqua forti y Perdoux Sculp. Sus dimensiones son: $27 \times 34,50 \mathrm{~cm}$.

[50] Plano geometral del Aqueducto en Mérida y del Puente de Albarregas. Figuran de izquierda a derecha el alzado de los dos arcos subsistentes del acueducto de San Lázaro en su estado real; detalle de la cornisa y de la sección transversal del puente del Albarregas y un alzado de la reconstitución de tres arcadas del acueducto de Los Milagros, con escalas gráficas diferentes para cada uno de los acueductos. Damos únicamente los alzados de ambos acueductos a la misma escala, que es diferente de las del dibujo.

Las indicaciones son: Molinier delineavit y Dor. nuer sculpsit.

[51] Grabado de la Crónica General de España. Pro. vincia de Badajoz, pág. 49 . 